\title{
Asteraceae Plants as Sources of Compounds Against Leishmaniasis and Chagas Disease
}

\author{
Roberval Nascimento Moraes Neto ${ }^{1 \dagger}$, Ruth Flávia Barros Setúbal ${ }^{1}$, \\ Taciana Mirely Maciel Higino ${ }^{2}$, Maria Carolina Accioly Brelaz-de-Castro ${ }^{3}$, \\ Luís Cláudio Nascimento da Silva ${ }^{1}$ and Amanda Silva dos Santos Aliança ${ }^{1 * \dagger}$ \\ ${ }^{1}$ Programa de Pós-Graduação da Universidade Ceuma, São Luís, Brazil, ${ }^{2}$ Departamento de Investigação Científica, \\ Fundação Altino Ventura, Recife, Brazil, ${ }^{3}$ Departamento de Enfermagem, Universidade Federal de Pernambuco, Vitória de \\ Santo Antão, Brazil
}

Leishmaniasis and Chagas disease cause great impact on social and economic aspects of people living in developing countries. The treatments for these diseases are based on the same regimen for over 40 years, thus, there is an urgent need for the development of new drugs. In this scenario, Asteraceae plants (a family widely used in folk medicine worldwide) are emerging as an interesting source for new trypanocidal and leishmanicidal compounds. Herein, we provide a non-exhaustive review about the activity of plant-derived products from Asteraceae with inhibitory action toward Leishmania spp. and T. cruzi. Special attention was given to those studies aiming the isolation (or identification) of the bioactive compounds. Ferulic acid, rosmarinic acid, and ursolic acid (Baccharis uncinella DC.) were efficient to treat experimental leishmaniasis; while deoxymikanolide (Mikania micrantha) and (+)-15-hydroxy-labd-7-en-17-al (Aristeguietia glutinosa Lam.) showed in vivo anti-T. cruzi action. It is also important to highlight that several plant-derived products (compounds, essential oils) from Artemisia plants have shown high inhibitory potential against Leishmania spp., such as artemisinin and its derivatives. In summary, these compounds may help the development of new effective agents against these neglected diseases.

Keywords: asteraceae plants, trypanosomatids, Trypanosoma cruzi, trypanocidal activity, Leishmania spp., leishmanicidal activity

\section{INTRODUCTION}

Protozoa are unicellular eukaryotes that cause some of the most common diseases in humans and domestic animals. These parasites have a range of habitats within their hosts, living in various parts of the body during their life cycle (Ullah et al., 2017). The Trypanosomatidae family includes several human-infective protozoans, such as Leishmania spp., and Trypanosoma cruzi, and they cause Leishmaniasis and Chagas disease, respectively. They affect mainly people living in developing countries, causing great disruption in their quality of life. These diseases are considered neglected diseases by the World Health Organization (WHO, 2013).

Leishmaniasis is considered one of the most significant neglected tropical diseases (Feasey et al., 2010). It is endemic in 98 countries with 350 million people at risk of getting the disease. The mortality rate is 70.000 cases/per year worldwide. Leishmaniasis has an incidence of 0.5 million cases of the visceral form and 1.5-2.0 million cases of cutaneous form (Blum et al., 2004; Reithinger et al., 2007a,b; WHO, 2016). Currently, therapeutic approaches for controlling 
leishmaniasis comprises only five drugs: the pentavalent antimonial, amphotericin B and its liposomal formulation AmBisome, miltefosine, paromomycin, and pentamidine. These drugs are associated with serious problems such as toxicity and emergence of drug-resistant strains (Tiwari and Dubey, 2018; Tiwari et al., 2018).

Chagas disease (or American trypanosomiasis) is the main cause of heart failure by an infection in Latin America, where the morbidity and mortality associated with this disease is superior to other neglected ones (malaria, schistosomiasis, and leishmaniasis; Martins-Melo et al., 2016). About 10 million infection cases and 14.000 deaths are recorded per year (Coura, 2015). Benznidazole (BNZ), which was developed over 40 years ago, is the first-line drug for the treatment of Chagas disease (Davanço et al., 2016). BNZ shows good efficacy in the acute phase of the disease (80-90\% cure), however its greatest restriction is the limited cure efficacy in the chronic phase, which is considered far of the ideal (8-20\%) (Bern, 2015). In addition, treatment with BNZ presents other problems, such as high administered doses, long term treatment and high incidence of adverse reactions, which are probably related to the generation of reactive metabolites produced from the metabolism of BNZ (Palmeiro-Roldan et al., 2014; Bermudez et al., 2016).

Since pharmaceutical companies neglect these diseases, there is an urgent demand to accelerate the development of more effective drugs against them. Plants are emerging as interesting sources of new trypanocidal and leishmanicidal compounds. They hold the promise for improvements in the field of drug development, and the ethnomedicinal knowledge plays an essential role in this process (Bermudez et al., 2016). For example, several plants from the Asteraceae family have provided some lead molecules against Leishmania spp. and T. cruzi (Sülsen et al., 2008; Beer et al., 2016; García et al., 2017; Kimani et al., 2017; Laurella et al., 2017). Indeed, Asteraceae plants play important ethnopharmacological role worldwide making them attractive candidates for drug development (Ali et al., 2017; Carvalho et al., 2018; Fattori et al., 2018; Naß and Efferth, 2018).

This paper provides a non-exhaustive overview on the contribution of Asteraceae family for the development of leishmanicidal and trypanocidal drugs. The search for papers was done between January and December of 2018, in PUBMED and Google Scholar databases. Special emphasis was given to those studies about the isolation of bioactive compounds and/or their in vivo evaluation. The ethnomedicinal uses of the plants listed in this work are summarized in Table 1. In addition, the structures of the most promising compounds (those that presented Selective index $\geq 5$ ) that are available at PubChem (https://pubchem.ncbi. nlm.nih.gov/) are shown in Figures 1, 2.

\section{PELLITORINE AND 8,9-Z-DEHYDROPELLITORINE FROM Achillea ptarmica L. ARE ACTIVE AGAINST TRYPANOSOMATIDS}

Extracts and isolated compounds of Achillea ptarmica L. flowers were tested against amastigote forms of $L$. donovani and $T$. cruzi. The cytotoxicity effects of each sample was evaluated using L6 cells (rat skeletal myoblasts), revealing that Pellitorine and 8,9-Z-Dehydropellitorine were the most promising compounds toward L. donovani [Selectivity Index (SI) of 7.6 and 3.2, respectively]. Pellitorine also showed activity against T. cruzi (SI: 5.34) (Althaus et al., 2014).

\section{COMPOUNDS FROM Ageratum conyzoides L. ARE ACTIVE AGAINST TRYPANOSOMATIDS}

Ageratum conyzoides L. is another Asteraceae plant with activity against trypanosomatids. The dichloromethane extract from $A$. conyzoides aerial parts was found to inhibit L. donovani [IC50 (concentration that inhibit $50 \%$ of parasite growth) $=3.4 \mu \mathrm{g} / \mathrm{mL}]$ and $T$. cruzi $(\mathrm{IC} 50=29 \mu \mathrm{g} / \mathrm{mL})$. The bio-guided fractionation allowed the isolation of the active compounds. Ageconyflavone $\mathrm{C}$ had the highest activity against $L$. donovani $(\mathrm{IC} 50=3.56 \mu \mathrm{g} / \mathrm{mL})$ with no measurable toxicity against L6 cells (SI >25.28); followed by $5^{\prime}$-methoxynobiletine ( $\left.\mathrm{SI}=3.6\right) .5,6,7,5^{\prime}$-Tetramethoxy- $3^{\prime}, 4^{\prime}$ methylenedioxyflavone was the most active compound against T. $\operatorname{cruzi}(\mathrm{IC50}=19.5 \mu \mathrm{g} / \mathrm{mL}$; SI >4.6; Nour et al., 2010). Encecalol angelate is another compound detected in the freshly prepared dichloromethane extract of A. conyzoides. As encecalol angelate was found to be unstable, a synthetic approach was employed to obtain this compound; however it displayed low antiprotozoal activity (Harel et al., 2011).

In addition, other report showed that the hydroalcoholic extract of A. conyzoides aerial parts inhibited promastigotes and trypomastigotes forms of L. amazonensis and T. cruzi (IC50 values of 107 and $104.7 \mu \mathrm{g} / \mathrm{mL}$, respectively), as well as the infective abilities of L. amazonensis and T. cruzi (Teixeira et al., 2014). However, the extract showed toxicity against J774.G8 macrophages.

\section{DITERPENOIDS FROM Aldama discolor ARE ACTIVE AGAINST TRYPANOSOMATIDS}

Aldama discolor (syn. Viguiera discolor Baker.) is an endemic plant from Brazilian Cerrado that showed inhibitory action against $L$. donovani and T. cruzi. Four diterpenoids were isolated from dichloromethane extract of $A$. discolor leaves: ent-3$\alpha$-hydroxy-kaur-16-en-18-ol, ent-7-oxo-pimara-8,15-diene-18ol, ent-2S,4S-2-19-epoxy-pimara-8(3),15-diene-7 $\beta$-ol and ent7-oxo-pimara-8,15-diene- $3 \beta$-ol. All compounds inhibited the growth of the amastigote forms from $L$. donovani and T. cruzi. Based on SI values obtained using L6 cells, the compound ent-3$\alpha$-hydroxy-kaur-16-en-18-ol (IC50 = 2.5 $\mu \mathrm{M}$; SI = 16) showed the highest effect against $L$. donovani; while ent-7-oxo-pimara8,15-diene-18-ol (IC50 = $15.4 \mu \mathrm{M}$; SI = 3) and ent-2S,4S-219-epoxy-pimara-8(3),15-diene-7 $\beta$-ol (IC50 = $19.4 \mu \mathrm{M}$; SI =4) were the most active against T. cruzi (Nogueira et al., 2016). 
TABLE 1 | Overview of selected Asteraceae plants with inhibitory activity toward Trypanosomatids.

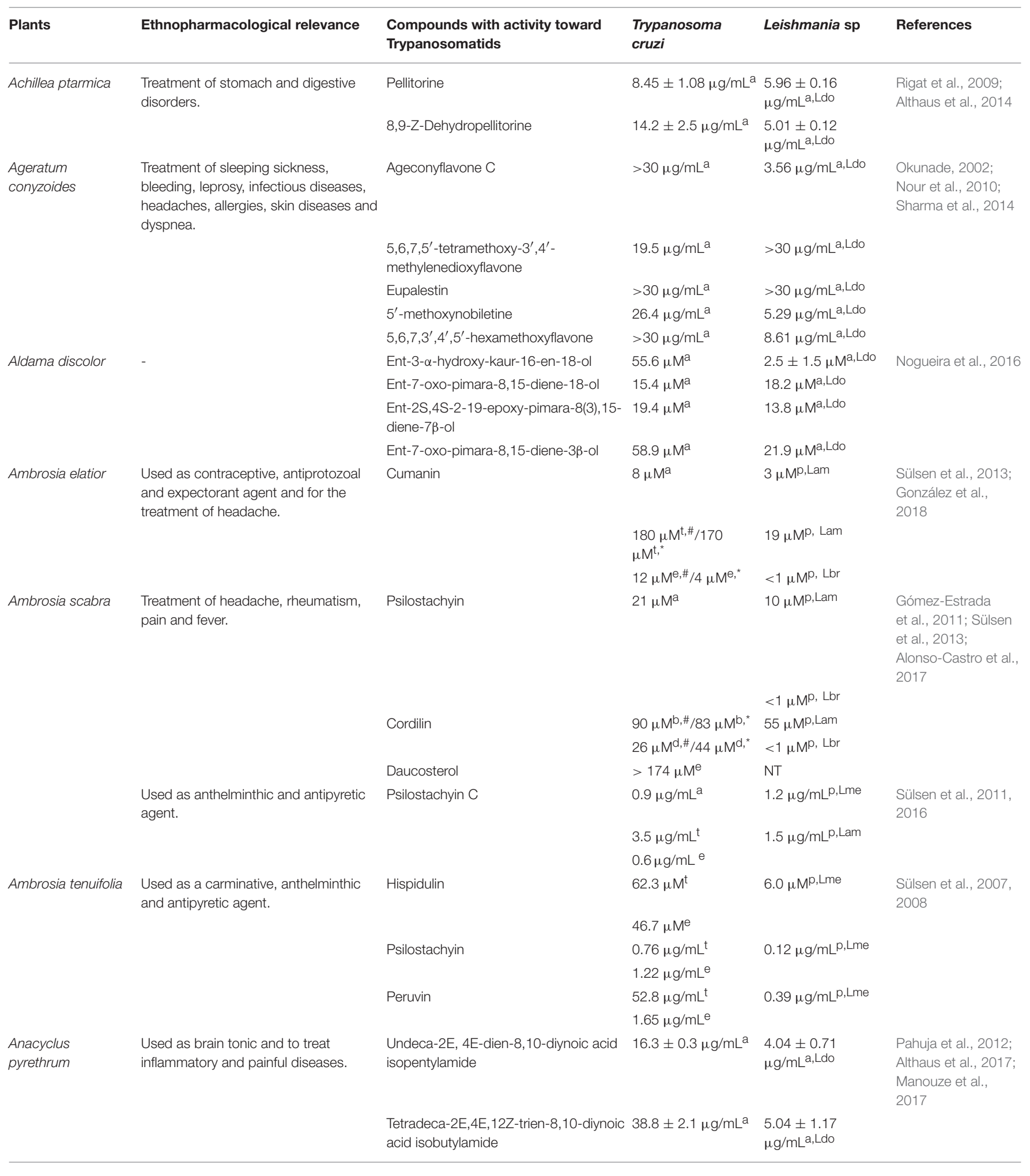


TABLE 1 | Continued

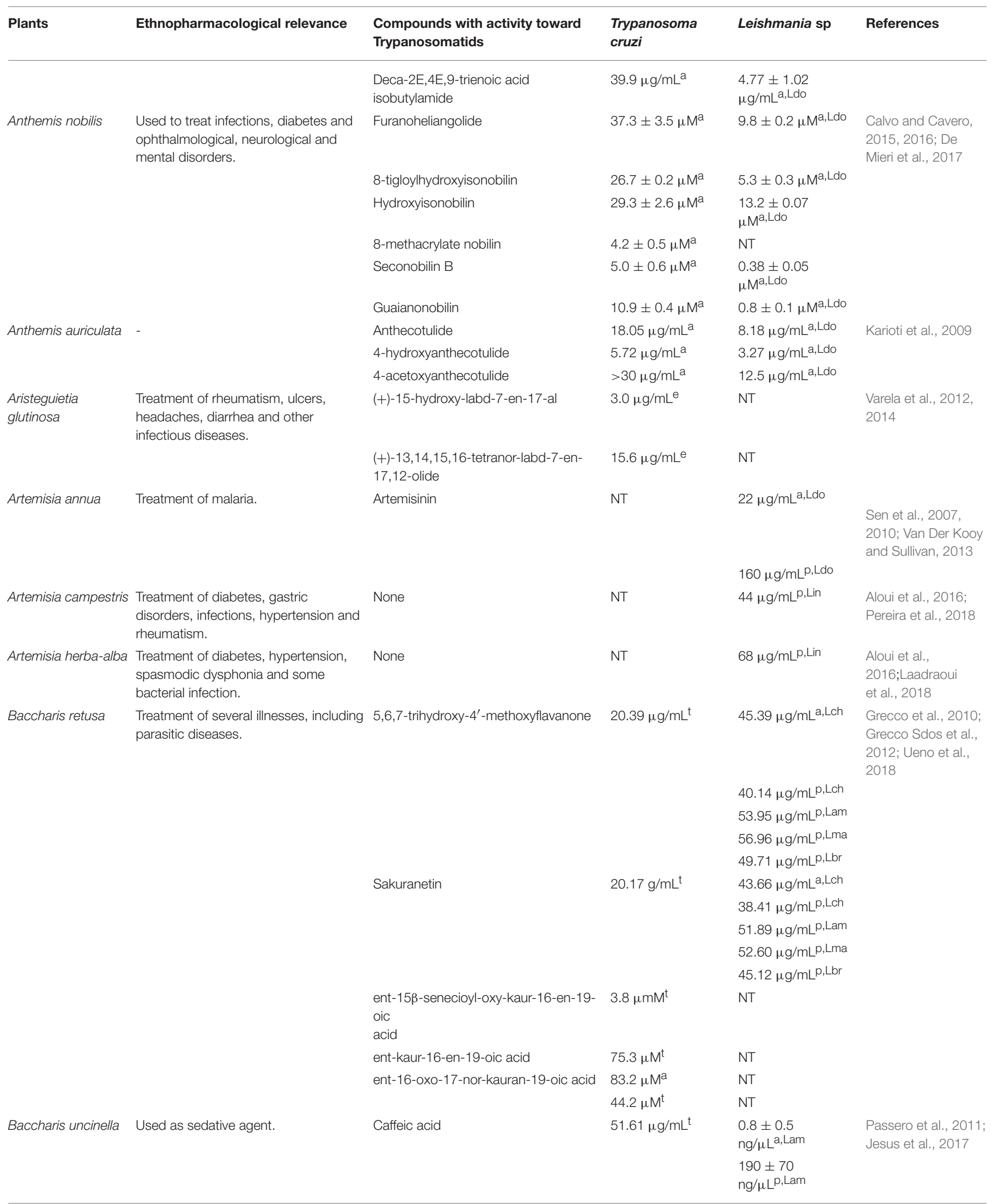


TABLE 1 | Continued

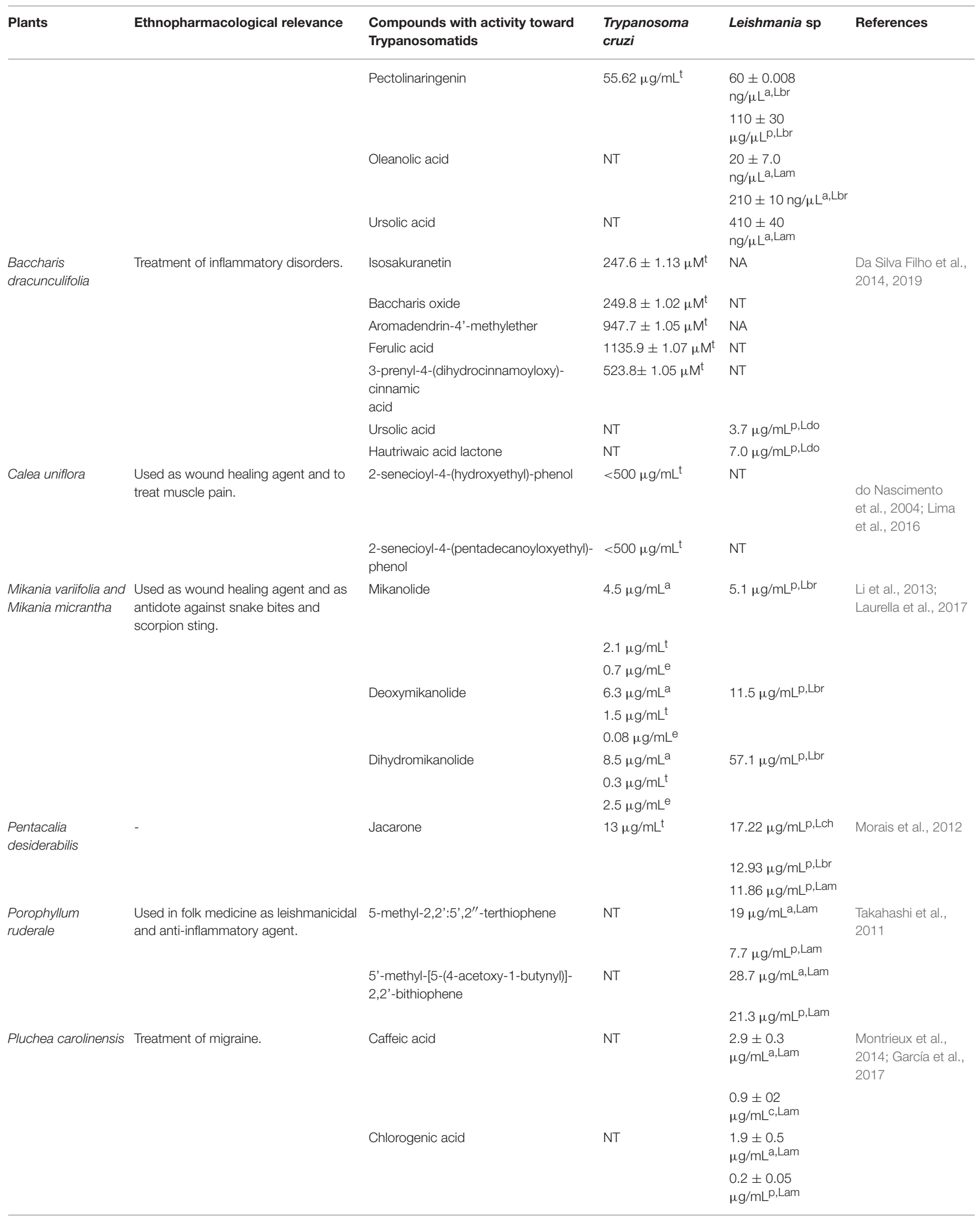


TABLE 1 | Continued

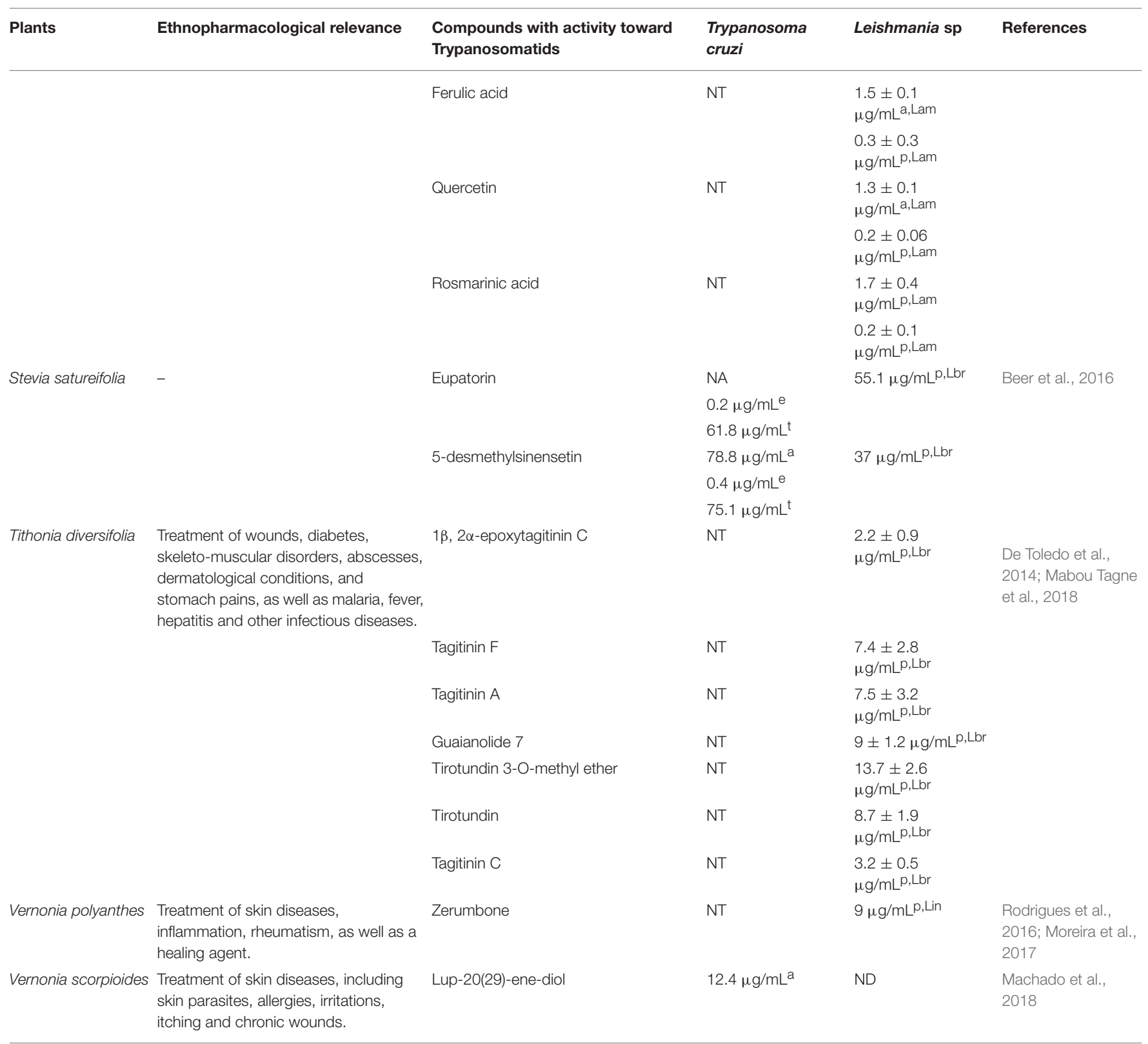

a, amastigote; $t$, trypomastigote; $p$, promastigote; e, epimastigote; Lam, L. amazonenses; Lbr, L. braziliensis; Lch, L. chagasi; Ldo, L. donovani; Lin, L. infantum; Lme, L. mexicana; NT, Not tested; ND, Not detected; NA, Not active; ${ }^{\#}$ T. cruzi RA strain; ' ${ }^{2}$. cruzi K98 strain.

\section{COMPOUNDS FROM Ambrosia PLANTS ARE ACTIVE AGAINST TRYPANOSOMATIDS}

The trypanocidal activity of Ambrosia plants was reported (Sülsen et al., 2006) and some active compounds were isolated, such as hispidulin (Sülsen et al., 2007), psilostachyin, and peruvin from Ambrosia tenuifolia Spreng (Sülsen et al., 2008); cumanin from Ambrosia elatior L. (Sülsen et al., 2013); damsin and confertin from Ambrosia peruviana Willd. Aponte et al. (2010); psilostachyin, cordilin, daucosterol (Sülsen et al., 2013), and psilostachyin C (Sülsen et al., 2011) from Ambrosia scabra Hook. \& Arn.

Hispidulin is a flavonoid isolated from the aerial parts of A. tenuifolia that showed action against epimastigotes (IC50 $=46.7 \mu \mathrm{M} ; \mathrm{SI}>3.6$ ) and trypomastigotes (IC50 $=62.3 \mu \mathrm{M}$; SI> 2.7) forms of T. cruzi; and it was high activity against L. mexicana promastigotes (IC50 $=6.0 \mu \mathrm{M}$; SI > 27.8). The toxicity was evaluated using lymphoid cells (Sülsen et al., 2007). This compound was also isolated from the aerial parts of Baccharis uncinella showing action against T. cruzi (Grecco Sdos et al., 2014). Although hispidulin has shown promising activity 


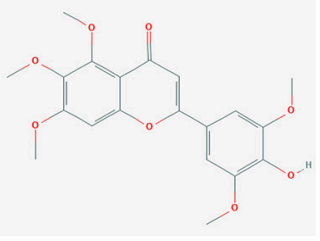

Ageconyflavone $\mathrm{C}$ $\left(\mathrm{C}_{20} \mathrm{H}_{20} \mathrm{O}_{8}\right)$

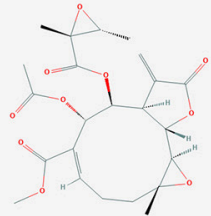

Enhydrin

$\left(\mathrm{C}_{23} \mathrm{H}_{28} \mathrm{O}_{10}\right)$

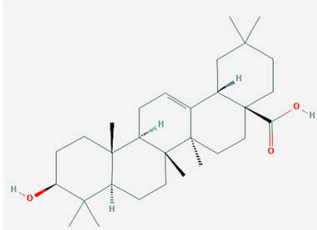

Oleanolic acid

$\left(\mathrm{C}_{30} \mathrm{H}_{48} \mathrm{O}_{3}\right)$

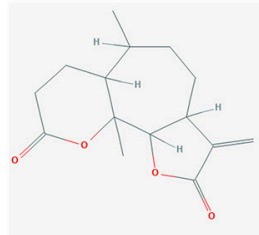

Psilostachyin

$\mathrm{C}\left(\mathrm{C}_{15} \mathrm{H}_{20} \mathrm{O}_{4}\right)$

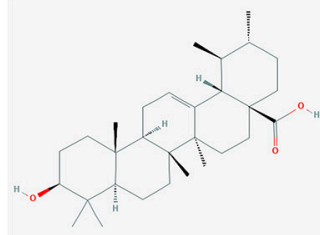

Ursolic acid

$\left(\mathrm{C}_{30} \mathrm{H}_{48} \mathrm{O}_{3}\right)$

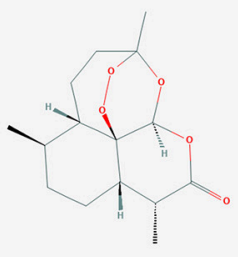

Artemisinin

$\left(\mathrm{C}_{15} \mathrm{H}_{22} \mathrm{O}_{5}\right)$

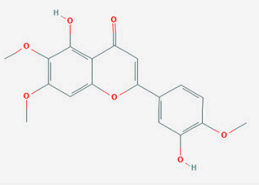

Eupatorin

$\left(\mathrm{C}_{18} \mathrm{H}_{16} \mathrm{O}_{7}\right)$

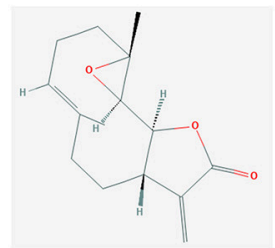

Parthenolide

$\left(\mathrm{C}_{15} \mathrm{H}_{20} \mathrm{O}_{3}\right)$

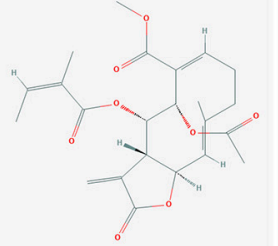

Polymatin B

$\left(\mathrm{C}_{23} \mathrm{H}_{28} \mathrm{O}_{8}\right)$

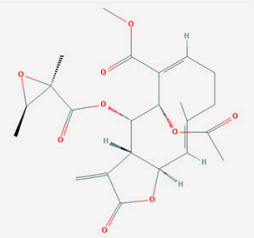

Uvedalin

$\left(\mathrm{C}_{23} \mathrm{H}_{28} \mathrm{O}_{9}\right)$

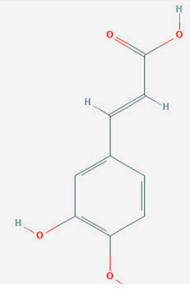

Caffeic acid

$\left(\mathrm{C}_{9} \mathrm{H}_{8} \mathrm{O}_{4}\right)$

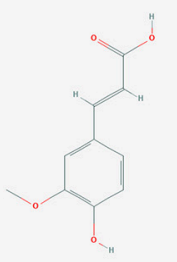

Ferulic acid

$\left(\mathrm{C}_{10} \mathrm{H}_{10} \mathrm{O}_{4}\right)$

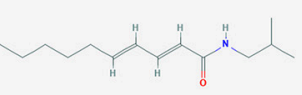

Pellitorine

$\left(\mathrm{C}_{14} \mathrm{H}_{25} \mathrm{NO}\right)$

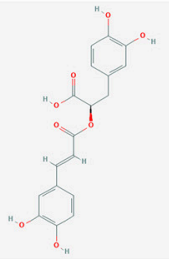

Rosmarinic acid

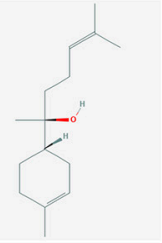

$\alpha$-Bisabolol

$\left(\mathrm{C}_{19} \mathrm{H}_{26} \mathrm{O}_{6}\right)$

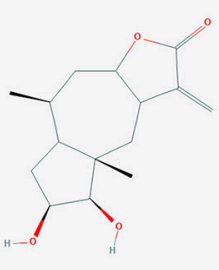

Cumanin

$\left(\mathrm{C}_{15} \mathrm{H}_{22} \mathrm{O}_{4}\right)$

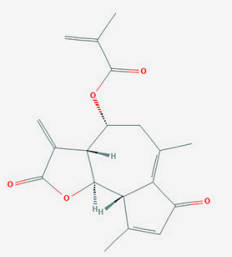

Guaianolide

$\left(\mathrm{C}_{19} \mathrm{H}_{20} \mathrm{O}_{5}\right)$

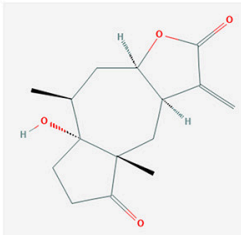

Peruvin $\left(\mathrm{C}_{15} \mathrm{H}_{20} \mathrm{O}_{4}\right)$

$\mathrm{SI}=89.7$

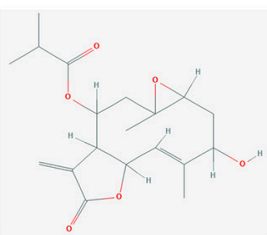

Tagitinin A

$\left(\mathrm{C}_{19} \mathrm{H}_{28} \mathrm{O}_{7}\right)$

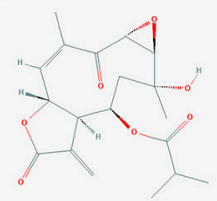

$1 \beta, 2 \alpha$-epoxytagitinin $\mathrm{C}$

$\left(\mathrm{C}_{19} \mathrm{H}_{24} \mathrm{O}_{7}\right)$

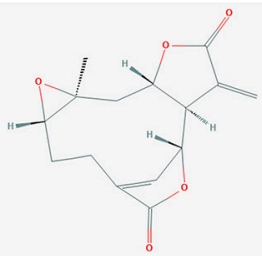

Deoxymikanolide

$\left(\mathrm{C}_{15} \mathrm{H}_{16} \mathrm{O}_{5}\right)$

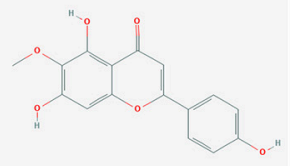

Hispidulin

$\left(\mathrm{C}_{16} \mathrm{H}_{12} \mathrm{O}_{6}\right)$

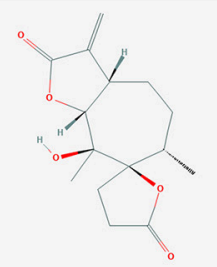

Psilostachyin
$\left(\mathrm{C}_{15} \mathrm{H}_{20} \mathrm{O}_{5}\right)$

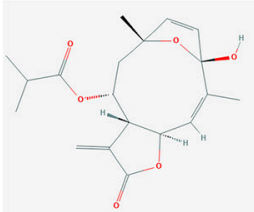

Tagitinin $\mathrm{F}$

$\left(\mathrm{C}_{19} \mathrm{H}_{24} \mathrm{O}_{6}\right)$

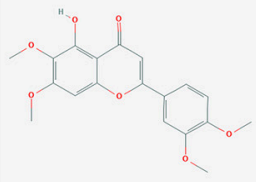

5-desmethylsinensetin $\left(\mathrm{C}_{19} \mathrm{H}_{18} \mathrm{O}_{7}\right)$

FIGURE 1 | Structures of high promising selected compounds with activity against Leishmania spp. All structures were obtained from Pubchem (https://pubchem. ncbi.nlm.nih.gov/). 


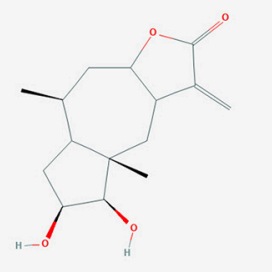

Cumanin
$\left(\mathrm{C}_{15} \mathrm{H}_{22} \mathrm{O}_{4}\right)$

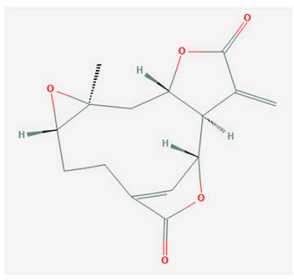

Deoxymikanolide $\left(\mathrm{C}_{15} \mathrm{H}_{16} \mathrm{O}_{5}\right)$

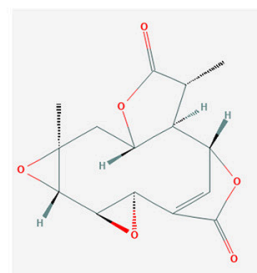

Dihydromikanolide $\left(\mathrm{C}_{15} \mathrm{H}_{16} \mathrm{O}_{6}\right)$

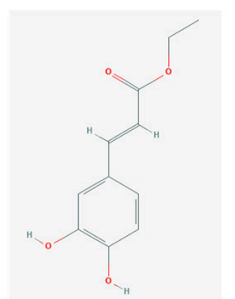

Ethyl Caffeate

$\left(\mathrm{C}_{11} \mathrm{H}_{12} \mathrm{O}_{4}\right)$

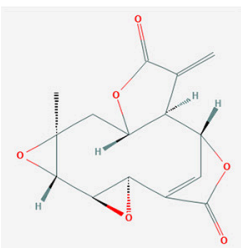

Mikanolide $\left(\mathrm{C}_{15} \mathrm{H}_{14} \mathrm{O}_{6}\right)$
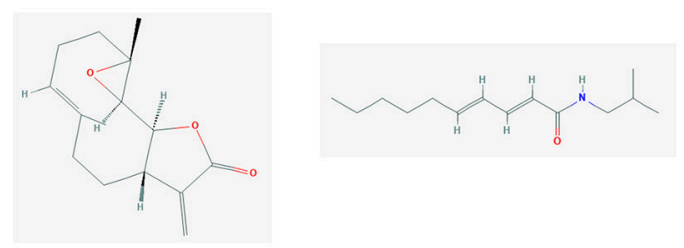

Parthenolide $\left(\mathrm{C}_{15} \mathrm{H}_{20} \mathrm{O}_{3}\right)$
Pellitorine

$\left(\mathrm{C}_{14} \mathrm{H}_{25} \mathrm{NO}\right)$

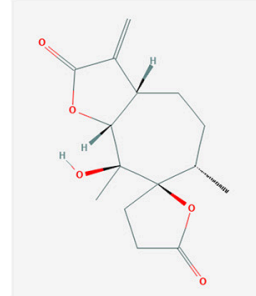

Psilostachyin

$\left(\mathrm{C}_{15} \mathrm{H}_{20} \mathrm{O}_{5}\right)$

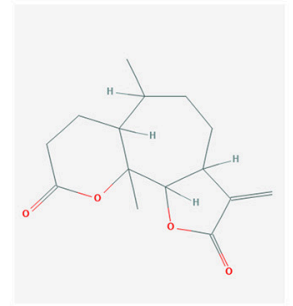

Psilostachyin $\mathrm{C}$

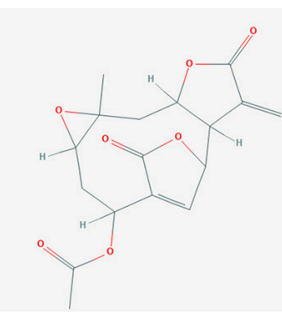

Scandenolide $\left(\mathrm{C}_{17} \mathrm{H}_{18} \mathrm{O}_{7}\right)$

FIGURE 2 | Structures of high promising selected compounds with activity against T. cruzi. All structures were obtained from Pubchem (https://pubchem.ncbi.nlm. nih.gov/).

against these trypanosomatids, there are no reports about its in vivo action.

Two sesquiterpene lactones were obtained from the aerial parts of A. tenuifolia (psilostachyin and peruvin) with anti-T. cruzi action (both with an IC50 of $2 \mu \mathrm{g} / \mathrm{mL}$ against epimastigotes forms). The authors also demonstrated the in vivo action of psilostachyin [the most active against trypomastigote forms; with an IC50 of $0.76 \mu \mathrm{g} / \mathrm{mL}$ and SI of 33.8 (tested using $\mathrm{T}$ lymphocytes)]. In addition, psilostachyin and peruvin also showed even higher activity against $L$. mexicana promastigotes with an IC50 values of $0.12 \mu \mathrm{g} / \mathrm{mL}(\mathrm{SI}=214.2)$ and $0.39 \mu \mathrm{g} / \mathrm{mL}$ $(\mathrm{SI}=89.7)$, respectively. In the experimental model of Chagas disease, the treatment with psilostachyin (or benznidazole) started 5 days post-infection; and it was performed by intraperitoneal route for 5 days ( $1 \mathrm{mg} / \mathrm{kg}$ of body weight/day). All psilostachyin-treated animals survived, while the mice in the other groups (untreated mice or animals treated with benznidazole) died after 35 days (Sülsen et al., 2008). However, other study reported that psilostachyin was not efficient in an acute model of T. cruzi infection. These different results may be explained by the differences in the treatment schedule in each study (Da Silva et al., 2013).

The anti-T. cruzi activity of the sesquiterpene lactone psilostachyin C isolated from A. scabra was also reported (Sülsen et al., 2011). In this study, the authors showed that psilostachyin C inhibited all forms of T. cruzi with low IC50 values (epimastigotes: $0.6 \mu \mathrm{g} / \mathrm{mL}$; trypomastigotes: $3.5 \mu \mathrm{g} / \mathrm{mL}$; and amastigotes: $0.9 \mu \mathrm{g} / \mathrm{mL}$ ) and high SI values (145.83, 97.22, and 25, respectively; when tested against murine peritoneal macrophages). The action of psilostachyin $\mathrm{C}$ on $T$. cruzi epimastigotes was associated with the induction of multivesicular bodies and vacuolization. Moreover, psilostachyin C also showed in vitro activity against the promastigote forms of L. mexicana $(\mathrm{IC} 50=1.2 \mu \mathrm{g} / \mathrm{mL} ; \mathrm{SI}=72.92)$ and $L$. amazonensis $(\mathrm{IC} 50=$ $1.5 \mu \mathrm{g} / \mathrm{mL}$; SI $=58.33$ ). Due the higher anti-T. cruzi properties of psilostachyin $\mathrm{C}$, the in vivo effects were evaluated in a murine model of Chagas disease. The administration of psilostachyin $\mathrm{C}$ ( $1 \mathrm{mg} / \mathrm{kg} /$ day during 5 days) to animals with 5 days of T. cruzi infection resulted in the reduction of parasitaemia and increased survival, a result similar to benznidazole (Sülsen et al., 2011).

Later, the mechanisms involved in the anti-T. cruzi actions of both psilostachyin (from A. tenuifolia) and psilostachyin C (from A. scabra) were evaluated by a range of in vitro assays. The study revealed that despite their chemical similarities and the fact that both compounds activated the apoptosis pathways, the effects of each compound are associated with different targets on epimastigotes forms: psilostachyin interact with hemin and psilostachyin $\mathrm{C}$ with sterol synthesis. In addition, the treatment with psilostachyin resulted in a 5-fold increase in the levels of reactive oxygen species (ROS), while psilostachyin $\mathrm{C}$ lead to a 1.5 increase in ROS quantities (Sülsen et al., 2016). These results may be associated to the ultrastructural alterations induced by psilostachyin that included mitochondrial swelling and kinetoplast abnormality (Sülsen et al., 2010). 
These effects were observed to psilostachyin C-treated parasites (Sülsen et al., 2011).

Other compound from the Ambrosia plants with promising action against trypanosomatids is cumanin, a sesquiterpene lactone isolated from A. elatior. Cumanin showed leishmanicidal (IC50 of $19 \mu \mathrm{M}$ against promastigote forms of L. braziliensis and L. amazonensis) and anti-T. cruzi activities (IC50 of 8,12 , and $180 \mu \mathrm{M}$ against amastigote, epimastigote and trypomastigote forms, respectively). The in vivo action of cumanin was also demonstrated in an experimental model of Chagas disease induced by intraperitoneal injection of the RA strain. Cumanin was administrated $(1 \mathrm{mg} / \mathrm{kg}$ of body weight/day by intraperitoneal route) for 5 days after the 5th day of parasite infection. The treatment with cumanin resulted in the survival of the T. cruzi-infected mice and in the reduction of parasitemia, effects similar to those found in the treatment with benznidazole. Moreover, this work also highlighted that cordilin was also active against $T$. cruzi (epimastigotes and trypomastigotes; Sülsen et al., 2013).

\section{ALKAMIDES FROM ANACYCLUS Pyrethrum (L.) LINK ARE ACTIVE AGAINST L. Donavani}

The dichloromethane extract obtained from the roots of Anacyclus pyrethrum (L.) Link was used for the isolation of alkamides with activity against $L$. donavani. L6 cells were used to evaluate the toxicity of each compound. Among the alkamides, undeca-2E,4E-dien-8,10-diynoic acid isopentylamide showed the best activity $(\mathrm{SI}=7)$, followed by tetradeca-2E,4E,12Z-trien-8,10-diynoic acid isobutylamide (SI = 3.9) and deca-2E,4E,9-trienoic acid isobutylamide $(\mathrm{SI}=3.5)$ (Althaus et al., 2017).

\section{COMPOUNDS DERIVED FROM Anthemis PLANTS ARE ACTIVE AGAINST TRYPANOSOMATIDS}

Anthemis nobilis L. [synonym of Chamaemelum nobile (L.) All.] is a plant know as Roman chamomile and used in folk medicine to treat infections and other disorders (Calvo and Cavero, 2015, 2016). The dichlomethane extract prepared from flowers of $A$. nobilis potently inhibited $L$. donovani promatigote forms (IC50 $=$ $1.40 \mu \mathrm{g} / \mathrm{mL}$ ). Several compounds were isolated from this extract and their activity was evaluated against $T$. cruzi intracellular amastigotes and $L$. donovani axenically grown amastigotes; while their toxicity was evaluated against L6 cells. Regarding the action against $T$. cruzi, the most active compound was 8-methacrylate nobilin (IC50 $=4.2 \mu \mathrm{M}$; SI $=6.1)$. Finally, seconobilin B (IC50 $=0.5 \mu \mathrm{M} ; \mathrm{SI}=11.2)$ and guaianonobilin $(\mathrm{IC} 50=0.8 \mu \mathrm{M}$; SI $=7.2$ ) showed the highest action against $L$. donovani (De Mieri et al., 2017). The aerial parts of Anthemis auriculata Boiss. have been also shown as sources of sesquiterpene lactones with antiprotozoa compounds: anthecotulide, 4-hydroxyanthecotulide, and 4-acetoxyanthecotulide. However, these compounds showed toxicity against L6 cells (Karioti et al., 2009).

\section{COMPOUNDS ISOLATED FROM Aristeguietia glutinosa ARE ACTIVE AGAINST T. cruzi}

The hydroalcoholic extract from aerial parts of Aristeguietia glutinosa (Lam.) R.M.King \& H.Rob and two diterpenoids [(+)15-hydroxy-labd-7-en-17-al and (+)-13,14,15,16-tetranor-labd7-en-17,12-olide] showed anti-T. cruzi action with IC50 values of $19.3,3.0$, and $15.6 \mu \mathrm{g} / \mathrm{mL}$, respectively. The compounds also showed low toxicity toward erythrocytes and murine macrophages (Varela et al., 2012). The in vivo actions of the hydroalcoholic extract $(50 \mathrm{mg} / \mathrm{kg})$ and $(+)$-15-hydroxy-labd-7en-17-al $(10 \mathrm{mg} / \mathrm{kg}$ or $30 \mathrm{mg} / \mathrm{kg})$ were evaluated in a BALB/c mice model of Chagas disease, and the treatment started 7 days after the infection. These agents reduced the amount of parasite in the blood leading to an increase in animal survival rates (Varela et al., 2014).

\section{COMPOUNDS ISOLATED FROM ARTEMISIA PLANTS ARE ACTIVE AGAINST Leishmania SPP.}

The genus Artemisia is composed by plants used for different ethnomedicinal practices (Bora and Sharma, 2011; Olennikov et al., 2018) and some Artemisia-derived compounds are promising anti-protozoa agents (Emami et al., 2012). In addition, a recent review showed the application of Artemisia plants and their constituents against Trypanosomiasis (Naß and Efferth, 2018). Since several papers evaluated the leishmanicidal effects of the Artemisia genus, in this section we reviewed studies where in vivo assays were employed along with the identification of the active(s) compound(s). In this sense, besides the studies discussed in this section, anti-Leishmania properties were also reported for extracts of Artemisia absinthium L. (Azizi et al., 2016), Artemisia dracunculus L. (Mirzaei et al., 2016; Rezaei et al., 2017), and Artemisia seiberi L. (Esavand Heydari et al., 2013).

Essential oils (EO) from some Artemisia plants have been pointed as interesting leishmanicidal agents (Abad et al., 2012), such as those obtained from Artemisia ludoviciana Nutt. (Baldemir et al., 2018) and Artemisia abyssinica Sch.Bip. ex A.Rich. (Tariku et al., 2010). For some of them, the in vivo properties were demonstrated; as an example the EO from Artemisia absinthium L. has inhibitory effects toward L. amazonensis (Monzote et al., 2014). A. absinthium EO was also evaluated against $L$. amazonensis in a murine model of experimental cutaneous leishmaniasis. The treatment with this oil $(30 \mathrm{mg} / \mathrm{kg}$ by intralesional route) was able to reduce the lesion size and parasite burden, even when compared with mice treated with glucantime (Monzote et al., 2014).

The EO from $A$. absinthium was also reported as active against $L$. aethiopica and $L$. donovani (Tariku et al., 2011). All these good results lead to the development of a new formulation of $A$. absinthium EO using nanocochleates. Although the formulation exhibited lower efficacy against the amastigote form of $L$. amazonensis, the animals that received 
4 administrations with this nanoformulation $(30 \mathrm{mg} / \mathrm{kg}$ by intralesional route) for 4 days exhibited smaller lesion size than the untreated mice or those treated with EO itself. The results were similar to those obtained with Glucantime ${ }^{\circledR}$ treatment (Tamargo et al., 2017).

The EOs from Artemisia campestris (L.) and Artemisia herbaalba (Asso.) were tested against promastigote forms of $L$. infantum showing IC50 values of 44 and $68 \mu \mathrm{g} / \mathrm{mL}$, respectively. The CC50 values obtained on peritoneal macrophages from $\mathrm{BALB} / \mathrm{c}$ treated with $A$. campestris and $A$. herba-alba were 124.4 and $160 \mu \mathrm{g} / \mathrm{mL}$, respectively, corresponding to a SI value of 2.82 for A. campestris and 2.35 for A. herba-alba. These oils showed different chemical compositions: A. campestris EO was mostly composed by monoterpene hydrocarbons (87\%) and its major compound was $\beta$-pinene (32.95\%); while A. herba-alba had high content of oxygenated monoterpenes $(85.79 \%)$ and its major compound was camphor (36.82\%). However, besides these chemical differences, the mechanisms of action of both EOs were related to apoptosis induction and cell cycle arrest (Aloui et al., 2016).

The EO obtained from leaves of Artemisia annua Pall. has also be shown as a potential alternative agent against Leishmaniasis. This EO has IC50 values of $14.63 \mu \mathrm{g} / \mathrm{mL}$ against promastigotes and $7.3 \mu \mathrm{g} / \mathrm{mL}$ against $L$. donovani amastigotes, without provoking toxic effects in RAW 264.7 macrophages (when tested up to $200 \mu \mathrm{g} / \mathrm{mL}$ ). This EO induced parasite apoptosis and its intra-peritoneal administration $(200 \mathrm{mg} / \mathrm{kg}$ ) was effective in the treatment of experimental $L$. donovaniinfected $\mathrm{BALB} / \mathrm{c}$ mice. The major compounds of this oil were camphor $(52.06 \%)$ and $\beta$-caryophyllene $(10.95 \%)$ (Islamuddin et al., 2014).

Another report showed that $\mathrm{n}$-hexane fraction from leaves and seeds of $A$. annua were active against $L$. donovani promastigotes (IC50 of 14.4 and $14.615 \mu \mathrm{g} / \mathrm{mL}$, respectively) and amastigotes forms (IC50 of 6.6 and $5.05 \mu \mathrm{g} / \mathrm{mL}$, respectively) and these effects were also related to apoptosis induction. The major compounds found in the leaves hexanic fraction were $\alpha$-amyrinyl acetate and $\beta$-amyrine; while the seed fraction showed cetin and nonacosane (EINECS 211-126-2). Both fractions were composed by derivatives of artemisinin (Islamuddin et al., 2012).

Artemisinin is a sesquiterpene lactone isolated from $A$. annua. Artemisinin and its derivatives were shown to inhibit L. donovani, L. infantum, and L. major (through the induction of parasite apoptosis; Sen et al., 2007, 2010; Cortes et al., 2015; Ghaffarifar et al., 2015). Due its lipophilic character, some leishmanicidal formulations containing artemisinin were already evaluated in models in vitro and in vivo, as examples: poly lactic co-glycolic acid nanoparticles (Want et al., 2014, 2015, 2017) and nanoliposomes (Want et al., 2017).

Later, it was demonstrated the in vivo action of the n-hexane fractions from leaves and seeds of A. annua in a murine model of visceral leishmaniasis caused by $L$. donovani. The authors reported that besides inducing direct inhibition of parasite growth, these extracts also activated the Th1 response with generation of immunological memory (Islamuddin et al., 2015). The efficacy of $A$. annua powder leaves was also confirmed in humans, where patients received capsules containing its powder (total of $30 \mathrm{~g}$ ) for over 20 days. Although this study only evaluated two patients, it is important to highlight that both were healed after the treatment and without any adverse effects or manifestations of the disease even up to 24 months after the cure (Mesa et al., 2017).

\section{COMPOUNDS FROM Baccharis GENUS ARE ACTIVE AGAINST TRYPANOSOMATIDS}

In relation to the Baccharis genus, three species have been reported as promising candidates for drug development: Baccharis retusa DC., B. uncinella DC., Baccharis dracunculifolia DC. The methanolic extracts from $B$. retusa leaves showed action against Leishmania spp. and T. cruzi, and a flavonoid (5,6,7-trihydroxy-4'-methoxyflavanone) was isolated. This compound inhibited both parasites, being better against T. cruzi trypomastigotes (IC50 $=20.39 \mu \mathrm{g} / \mathrm{mL}$ ), however it showed moderate toxicity toward THP-1 $(\mathrm{SI}=2.43)$ and MK2 $(\mathrm{SI}=$ 0.66 ) cells (Grecco et al., 2010). Sakuranetin is another flavonoid extracted from $B$. retusa that showed activity against $T$. cruzi trypomastigotes (IC50 $=20.17 \mu \mathrm{g} / \mathrm{mL}$ ) and Leishmania spp. promastigotes (IC50 $=43 \mu \mathrm{g} / \mathrm{mL}$ to $52 \mu \mathrm{g} / \mathrm{mL}$ ), however it also showed significant toxicity on peritoneal macrophages from BALB/c mice (Grecco Sdos et al., 2012).

A recent work reported the isolation of three diterpenes from the aerial parts of $B$. retusa with anti-T. cruzi properties: ent-15 $\beta$-senecioyl-oxy-kaur-16-en-19-oic acid; ent-kaur-16-en19-oic acid; and ent-16-oxo-17-nor-kauran-19-oic acid. These compounds were more effective against trypomastigotes, and only ent-16-oxo-17-nor-kauran-19-oic acid was active against the amastigote form. The most active against the trypomastigotes forms was ent-15 $\beta$-senecioyl-oxy-kaur-16-en-19-oic acid (IC50 $=3.8 \mu \mathrm{M} ; \mathrm{SI}=50$ as determined using NCTC cells-clone L929) and its effects were related to interference in the permeability of the plasma membrane of the parasite (probably due its lipophilic characteristics; Ueno et al., 2018).

Anti-Leishmania compounds (caffeic acid, pectolinaringenin; and one fraction composed by oleanolic acid and ursolic acid) were isolated from ethanolic extract of $B$. uncinella aerial parts. These compounds exhibited low cytotoxicity toward J774 macrophages. Pectolinaringenin and the combination of oleanolic and ursolic acids were appointed as the most active compounds against amastigote forms of $L$. amazonensis and L. braziliensis (Passero et al., 2011). In a similar work, the action of the compounds isolated from ethanolic extracts of B. uncinella aerial parts were also analyzed against T. cruzi: caffeic acid $(\mathrm{IC} 50=51.61 \mu \mathrm{g} / \mathrm{mL})$, pectolinaringenin $(\mathrm{IC} 50=$ $55.62 \mu \mathrm{g} / \mathrm{mL}$ ), hispidulin $(\mathrm{IC} 50=80.61 \mu \mathrm{g} / \mathrm{mL}$ ) and a mixture of three chrogenic acids (3,4-, 3,5-, and 4,5-O-dicaffeoylquinic acids; IC50 $=61.04 \mu \mathrm{g} / \mathrm{mL})$ (Grecco Sdos et al., 2014).

These in vitro results encouraged the evaluation of the leishmanicidal properties of the fraction containing oleanolic and ursolic acids obtained from leaves of B. uncinella in a model of Tegumentar Leishmaniasis induced by L. amazonensis. Mice treated with this triterpenic fraction (at 1.0 or $5.0 \mathrm{mg} / \mathrm{kg}$ ) 
showed lower levels of parasitism in the skin and decreased lesion size than untreated animals. These effects were similar to those observed for amphotericin B-treated mice. In both fractiontreated groups were also observed high amounts of interleukin12 and interferon gamma (Yamamoto et al., 2014).

Later, it was reported that ursolic acid showed more potent action against L. amazonensis promastigotes than oleanolic acid. The effects of ursolic acid toward promastigotes were associated with activation of programmed cell death in a pathway dependent of mitochondria activity but not related to caspase 3/7. Only ursolic acid was able to eradicate the amastigotes by increasing the release of nitric oxide by peritoneal macrophages. The efficacy of ursolic acid was also proven in vivo using BALB/c mice infected L. amazonensis (Yamamoto et al., 2015). However, oleanolic acid has been highlighted in other works as an important lead molecule for development of drugs for treatment of leishmaniosis (Sifaoui et al., 2014, 2017; Ghosh et al., 2016; Melo et al., 2016; Pertino et al., 2017).

Recently, the ursolic acid obtained from leaves of $B$. uncinella was also shown as a potent agent against experimental visceral leishmaniasis caused by L. infantum. The intraperitoneal injection of ursolic acid (1.0 or $2.0 \mathrm{mg} / \mathrm{kg}$ ) reduced the parasites load in spleen and liver, induced the proliferation of splenic mononuclear cells and the production of IFN- $\gamma$ and nitric oxide (Jesus et al., 2017). Additionally, a nanostructured lipid carrier system coated with N-octyl-chitosan surface for improve the delivery of ursolic acid was developed for treatment of visceral leishmaniosis induced by $L$. donovani. The oral treatment with this preparation was more effective than free ursolic acid treatment and reduced the parasite load in the spleen (Das et al., 2017).

Regarding B. dracunculifolia (the most important source of the Brazilian green propolis), the extract from leaves showed anti-T. cruzi effects and five active compounds were obtained; among them, isosakuranetin and baccharis oxide showed the best inhibitory potentials with IC50 values of 247.6 and $249.8 \mu \mathrm{M}$, respectively. Other compounds [aromadendrin-4'-methylether, ferulic acid, and 3-prenyl-4-(dihydrocinnamoyloxy)-cinnamic acid] were classified as moderated inhibitors. The authors did not evaluated the toxicity of these compounds (Da Silva Filho et al., 2014). On the other hand, the most active anti-L. donovani agents obtained from $B$. dracunculifolia were ursolic acid (IC50 $=3.7 \mu \mathrm{g} / \mathrm{mL})$ and hautriwaic acid lactone $($ IC50 $=7.0 \mu \mathrm{g} / \mathrm{mL}$; Da Silva Filho et al., 2014). Further, the EO from leaves of $B$. dracunculifolia showed action against the promastigote forms of L. donovani (IC50: $42 \mu \mathrm{M}$ ). This oil had (E)-nerolidol (33.51\%) and spathulenol (16.24\%) as major compounds. The oil was not toxic to Vero cells at the tested concentrations (Parreira et al., 2010).

\section{COMPOUNDS ISOLATED FROM Calea PLANTS ARE ACTIVE AGAINST TRYPANOSOMATIDS}

In relation to plants belonging to the Calea genus, antitrypanosomatids compounds have been isolated from two species: Calea pinnatifida (R.Br.) Less. and Calea uniflora Less. This last species is a plant with ethnomedicinal importance in the state of Santa Catarina (Brazil), however there are few scientific studies about its pharmacological properties (Ramos et al., 2016). Two p-hydroxyacetophenone derivatives [2-senecioyl-4-(hydroxyethyl)-phenol and 2senecioyl-4-(pentadecanoyloxyethyl)-phenol] obtained from dichloromethane extract of $C$. uniflora reduced the viability of $T$. cruzi trypomastigotes by 70 and $71 \%$, respctively (at a $500 \mu \mathrm{g} / \mathrm{mL}$ dose) (do Nascimento et al., 2004). Similarly, two chromanones [uniflorol-A and uniflorol-B] from this extract inhibited $88.9 \%$ of L. major promastigotes growth at a concentration of $100 \mu \mathrm{g} / \mathrm{mL}$ (Do Nascimento et al., 2007). The authors did not report the toxicity of these compounds above discussed.

Other compounds with promising inhibitory action toward T. cruzi amastigotes were isolated from dichloromethane and ethyl acetate fractions of $C$. uniflora leaves. Among them, ethyl caffeate showed the best activity with an IC50 of $18.27 \mu \mathrm{g} / \mathrm{mL}$ (SI $=12.95)$, while the mixture of butein and orobol $(1: 1)$ showed an IC50 of $26.53 \mu \mathrm{g} / \mathrm{mL}(\mathrm{SI}=3.61)$. The toxicity of these compounds was evaluated using THP-1 cells. The author also investigated the inhibitory action of the compounds isolated from C. uniflora leaves against L. amazonensis amastigotes, however no promising results were found (Lima et al., 2016).

In another work, two chromenes extracted from leaves of $C$. pinnatifida showed moderate activity against L. amazonensis amastigotes: 6-acetyl-7-hydroxy-2,2-dimethylchromene (eupatoriochromene; inhibition of 39.3\%) and 6-(1Hydroxyethyl)-7-methoxy-2,2-dimethylchromene (encecalinol; inhibition of $32.3 \%$ ). The authors only performed an inhibition assay using the dose of $50 \mu \mathrm{g} / \mathrm{mL}$; and the toxicity of these compounds was not reported in this study (Lima et al., 2015). Later, the compound 11,13-dihydroxy-calaxin (a new furanoheliangolide sesquiterpene lactone) was able to inhibit amastigotes of $T$. cruzi and L. amazonensis, when tested at $50 \mu \mathrm{M}$, however, this compound showed high cytotoxicity against THP-1 cell (the SI was not determined; Lima et al., 2017).

\section{SESQUITERPENES ISOLATED FROM Mikania SPECIES ARE ACTIVE AGAINST T. cruzi}

The genus Mikania has been pointed as a source of bioactive compounds, based on this, the extracts of four species (Mikania micrantha Kunth, Mikania parodii Cabrera, Mikania periplocifolia Hook. \& Arn, and Mikania cordifolia (L.f.) Willd.) were evaluated against T. cruzi and L. braziliensis. The organic extracts (prepared with dichloromethane/methanol solution; 1:1) of the four Mikania species exhibited inhibitory activity against both pathogens, however the M. micrantha extract was the most active, inhibiting by 77.6 and $84.9 \%$ the growth of epimastigotes and promastigotes of $T$. cruzi and L. braziliensis, respectively (Laurella et al., 2012).

Later, sesquiterpene lactones with inhibitory action against $T$. cruzi and L. braziliensis were obtained from dichloromethane extracts of M. micrantha and Mikania variifolia Hieron. 
The obtained compounds inhibited the amastigote and trypomastigote stages of T. cruzi. The higher SI values (as determined using human monocyte leukemia THP1 cells) for trypomastigotes were found to deoxymikanolide $(\mathrm{SI}=54)$ and dihydromikanolide (SI $=49.9$ ), followed by scandenolide (SI = 12.6) and mikanolide (SI = 10.7); while for amastigotes the order was scandenolide (SI $=14.2$ ), deoxymikanolide (SI $=12.5$ ), mikanolide (SI = 4.3), and dihydromikanolide (SI $=1.5$ ). Furthermore, mikanolide (IC50 $=5.1 \mu \mathrm{g} / \mathrm{mL}$; SI $=$ 4.4) and deoxymikanolide (IC50 $=11.5 \mu \mathrm{g} / \mathrm{mL}$; SI $=6.9$ ) also demonstrated strong inhibitory effects toward L. braziliensis. Based on SI index for both amastigote and trypomastigote forms, deoxymikanolide was also evaluated in an in vivo model of lethal T. cruzi infection, where it reduced the parasite load and increased the mice survival (Laurella et al., 2017). The anti-T. cruzi activity of deoxymikanolide is related to reduction of thiol groups leading to more susceptibility for oxidative stress, inhibition of parasite antioxidant defense and induction of mitochondrial dysfunction (Puente et al., 2018).

\section{JACARANONE FROM Pentacalia desiderabilis IS ACTIVE AGAINST TRYPANOSOMATIDS}

Jacaranone is a compound extracted from leaves of Pentacalia desiderabilis (Vell.) Cuatrec that showed inhibitory action against L. chagasi, L. braziliensis, and L. amazonensis with low IC50 values (ranging from 11.86 to $17.22 \mu \mathrm{g} / \mathrm{mL}$ ); it was also active against $T$. cruzi trypomastigotes (IC50 $=13 \mu \mathrm{g} / \mathrm{mL}$ ). However, this compound did not show activity against the amastigote forms of $L$. chagasi and T. cruzi. The cytotoxicity studies using MK2 cells suggested that jacaranone is not a promising compound for treatment of leishmaniosis and Chagas disease (Morais et al., 2012).

\section{COMPOUNDS FROM PLUCHEA CAROLINENSIS ARE ACTIVE AGAINST LEISHMANIA SPP.}

An initial screening using different extracts/fractions of Pluchea plants ( $P$. carolinensis, $P$. rosea and $P$. odorata), revealed that ethanol (IC50 $=30.4 \mu \mathrm{g} / \mathrm{mL}$; SI $=6)$ and n-hexane (IC50 = $54.5 \mu \mathrm{g} / \mathrm{mL}$; SI $=4$ ) extracts from Pluchea carolinensis (Jacq.) D.Dom were the most promising anti-L. amazonensis agent. The author also reported that the intraperitoneal administration of the ethanol extract $(100 \mathrm{mg} / \mathrm{kg})$ reduced the formation of lesions induced by L. amazonensis in mice (García et al., 2011).

Other work evaluated the in vitro and in vivo antiLeishmania action of major phenolic constituents of $P$. carolinensis (caffeic acid, chlorogenic acid, ferulic acid, quercetin, and rosmarinic acid). All compounds inhibited promastigotes (IC50 $=0.2-0.9 \mu \mathrm{g} / \mathrm{mL}$ ) and intracellular amastigotes (IC50 $=1.3-2.9 \mu \mathrm{g} / \mathrm{mL}$ ). Caffeic acid (IC50 = $180.5 \mu \mathrm{g} / \mathrm{mL}$ ), ferulic acid $(\mathrm{IC50}=129.03 \mu \mathrm{g} / \mathrm{mL})$ and rosmarinic acid (IC50 = $93.1 \mu \mathrm{g} / \mathrm{mL}$ ) were selected after cytotoxicity testing toward mouse peritoneal macrophages, with SI values of 11, 17, and 20 , respectively. These three compounds were efficient in an experimental cutaneous leishmaniasis model induced by $L$. amazonensis. The treatment started 15 days after the infection and was done in five doses (30 $\mathrm{mg} / \mathrm{kg}$ by intralesional route) each 4 days. All compounds showed in vivo efficacy higher than glucantime; ferulic acid showed the best active reducing the lesion size and parasite burden (Montrieux et al., 2014).

$P$. carolinensis $\mathrm{EO}$ also showed activity against both amastigote $(\mathrm{IC} 50=6.2 \mu \mathrm{g} / \mathrm{mL})$ and promastigote $(\mathrm{IC} 50=24.7 \mu \mathrm{g} / \mathrm{mL})$ forms of L. amazonensis, while cytotoxicity assay revealed a CC50 value of $28.3 \mu \mathrm{g} / \mathrm{mL}$ against peritoneal macrophage from $\mathrm{BALB} / \mathrm{c}(\mathrm{SI}=5)$. The intralesional application of this EO (30 $\mathrm{mg} / \mathrm{kg}$ ) resulted in the reduction of parasite burden and lesion size in mice, even when compared with those animals treated with Glucantime ${ }^{\circledR}$. The major component in this EO was selin11-en-4 $\alpha$-ol (about 51\%), however, the authors did not tested it (García et al., 2017).

\section{THIOPHENE DERIVATIVES ISOLATED FROM Porophyllum ruderale ARE ACTIVE AGAINST Leishmania SPP.}

Porophyllum ruderale (Jacq.) Cass. is a plant used in folk medicine to treat leishmaniasis. Based on this, the inhibitory activity of the dichloromethane extract obtained from the aerial parts of $P$. ruderale and its compounds were evaluated against $L$. amazonensis. The dichloromethane extract was active for both promastigote $(\mathrm{IC} 50=60.3 \mu \mathrm{g} / \mathrm{mL}$; SI $=8.3$ ) and amastigote (IC50 $=77.7 \mu \mathrm{g} / \mathrm{mL}$; SI $=6.5 \mu \mathrm{g} / \mathrm{mL}$ ) forms. The cytotoxicity was determined using J774G8 macrophages. The bio-guided isolation lead to the identification of two thiophene derivatives as active compounds: 5-methyl-2,2':5',2 $2^{\prime \prime}$-terthiophene and $5^{\prime}$-methyl[5-(4-acetoxy-1-butynyl)]-2,2'-bithiophene. The compound 5methyl-2,2':5',2'-terthiophene showed the best action with an IC50 value of $7.7 \mu \mathrm{g} / \mathrm{mL}$ (against promastigotes) and $19.0 \mu \mathrm{g} / \mathrm{mL}$ (against amastigotes) with SI values of 48.2 and 19.1, respectively. Meanwhile, 5'-methyl-[5-(4-acetoxy-1-butynyl)]$2,2^{\prime}$-bithiophene showed an IC50 and SI values of $21.3 \mu \mathrm{g} / \mathrm{mL}$ and 15.7 for promastigotes; and $28.7 \mu \mathrm{g} / \mathrm{mL} 11.7$ for amastigotes (Takahashi et al., 2011).

In addition, Takahashi et al. (2013) provided some insights into the action of these thiophene derivatives. The authors showed that although both compounds were not able to induce damage in the parasite membrane, the 5-methyl- $2,2^{\prime}: 5^{\prime}, 2^{\prime \prime}$ terthiophene provoked depolarization of mitochondrial membrane potential of $L$. amazonensis promastigotes. The ultrastructural analysis confirmed this effect since mitochondria swelling were observed for promastigote and amastigote forms treated with 5 -methyl-2,2' $: 5^{\prime}, 2^{\prime \prime}$-terthiophene (Takahashi et al., 2013).

\section{SESQUITERPENE LACTONES FROM Smallanthus sonchifolius ARE ACTIVE AGAINST TRYPANOSOMATIDS}

The plant Smallanthus sonchifolius (Poepp.) H.Rob. has also been demonstrated as a source of sesquiterpene lactones with activity against trypanosomatids. A bio-guided assay using the 
epimastigote forms of $T$. cruzi led to the isolation of three active compounds from the dichloromethane extracts from $S$. sonchifolius leaves: enhydrin $($ IC50 $=0.84 \mu \mathrm{M})$, uvedalin (IC50 $=1.09 \mu \mathrm{M})$, and polymatin $\mathrm{B}(\mathrm{IC50}=4.90 \mu \mathrm{M})$. Enhydrin and uvedalin were active against trypomastigotes with an IC50 of $33.4 \mu \mathrm{M}$ and $25.0 \mu \mathrm{M}$, respectively. Polymatin B did not inhibit the trypomastigote form. In addition, these sesquiterpene lactones inhibited the amastigote forms with uvedalin showing the best activity $(\mathrm{IC} 50=1.09 \mu \mathrm{M})$, followed by enhydrin (IC50 = $3.34 \mu \mathrm{M})$ and polymatin $\mathrm{B}(\mathrm{IC} 50=9.02 \mu \mathrm{M})$. Finally, the toxicity was evaluated against Vero cells, revealing that all compounds have more specificity for the amastigotes, as the SI were 16.3, 14 and 9 for polymatin B, uvedalin, and enhydrin, respectively (Frank et al., 2013).

The in vivo effects of uvedalin and enhydrin was evaluated in a model of T. cruzi infection in mice. Both compounds were administrated by intraperitoneal injections $(1 \mathrm{mg} / \mathrm{kg}$ of body weight/day) on the 7 th day post-infection and the treatment was performed for 5 consecutive days. The animals treated with uvedalin or enhydrin exhibited lower levels of parasitaemia, and these effects were similar to those obtained with benznidazole (positive control). Mice treated with these sesquiterpene lactones also showed higher survival ratios and reduced weight loss when compared to untreated animals (Ulloa et al., 2017).

Enhydrin, uvedalin, and polymatin B also showed antiLeishmania activity when tested against $L$. mexicana. These compounds showed high leishmanicidal activity toward the promastigote form with IC50 values of $0.92 \mu \mathrm{M}$ (enhydrin), $0.93 \mu \mathrm{M}$ (uvedalin), and $1.04 \mu \mathrm{M}$ (polymatin $\mathrm{B}$ ). The action of these sesquiterpene lactones was better than the positive control, amphotericin B $($ IC50 $=2 \mu \mathrm{M})$. As seen with the anti-T. cruzi activity, the highest activity toward intracellular form of $L$. mexicana was observed for uvedalin (IC50 = 1.89 $\mu \mathrm{M})$, followed for enhydrin (IC50 = 3.66 $\mu \mathrm{M}$; Ulloa et al., 2017).

\section{FLAVONOIDS FROM Stevia satureifolia ARE ACTIVE AGAINST TRYPANOSOMATIDS}

The dichloromethane extract from aerial parts of Stevia satureifolia (Lam.) Sch. Bip. var. satureifolia showed inhibitory action against $L$. braziliensis and T. cruzi. A bio-guided approach resulted in the isolation of two active flavonoids: eupatorin $(\mathrm{IC} 50=0.2 \mu \mathrm{g} / \mathrm{mL}$ for amastigotes and $61.8 \mu \mathrm{g} / \mathrm{mL}$ for trypomastigotes) and 5-desmethylsinensetin (IC50 = $0.4 \mu \mathrm{g} / \mathrm{mL}$ for amastigotes and $75.1 \mu \mathrm{g} / \mathrm{mL}$ for trypomastigotes). 5-desmethylsinensetin showed the best activity against $L$. braziliensis promastigotes (IC50 = 37.0 $\mathrm{g} / \mathrm{mL}$ ). Both compounds had low cytotoxicity toward Vero cells (CC50 $>500 \mu \mathrm{g} / \mathrm{mL}$; and SI > 13.5; Beer et al., 2016).

\section{SESQUITERPENE LACTONES FROM Tanacetum parthenium ARE ACTIVE AGAINST TRYPANOSOMATIDS}

Two sesquiterpene lactones with activity against trypanosomatids were isolated from Tanacetum parthenium (L.) Sch.Bip.: guaianolide and parthenolide. Guaianolide was obtained from the hydroalcoholic extract of the aerial parts of T. parthenium, and it showed an IC50 value of $2.6 \mu \mathrm{g} / \mathrm{mL}$ toward promastigote forms of $L$. amazonensis. It was also active against the amastigote form, reducing their survival to $10 \%$ when compared to untreated cells. The cytotoxicity analysis, carried out with J774G8 cells, revealed that this compound displayed a high selectivity toward the parasite $(\mathrm{SI}=385)$. The effects of guaianolide on promastigotes were associated to severe morphological alterations including changes in size, shape and number of flagellum (Da Silva et al., 2010).

Guaianolide was also effective against all forms of $T$. cruzi with IC50 values of $5.7 \pm 0.7,18.1 \pm 0.8,66.6 \pm$ $1.3 \mu \mathrm{M}$ for trypomastigote $(\mathrm{SI}=16.4$ ), epimastigote and amastigote $(\mathrm{SI}=1.40)$ forms. The ultrastructural modifications induced by guaianolide involved the reduction of cell size for trypomastigotes and epimastigotes; and decrease in mitochondrial membrane potential in epimastigotes. Further, guaianolide also exhibited synergistic effect with benznidazole against the epimastigote forms and additive effects against the trypomastigote forms (Cogo et al., 2012).

Similarly, parthenolide was also isolated from the aerial parts of T. parthenium and exhibited activity against L. amazonensis (Tiuman et al., 2005) and T. cruzi (Izumi et al., 2008). When concerning the anti- L. amazonensis activity, parthenolide showed IC50 values of $0.37 \mu \mathrm{g} / \mathrm{mL}$ and $0.81 \mu \mathrm{g} / \mathrm{mL}$ toward promastigote and amastigote forms, without inducing toxic effects against J774G8 macrophages and sheep erythrocytes. The leishmanicidal activity was associated to an increase in the lysosomes size and in the exocytose in the region of the flagellar pocket (Tiuman et al., 2005). New insights on the action mechanism of parthenolide against amastigote forms of L. amazonensis were provided by the work of Tiuman et al. (2014). This research showed that parthenolide effect was associated with the appearance of autophagic vacuole, loss of membrane integrity, and mitochondrial dysfunction. In addition, parthenolide did not induce genotoxic effects in mice, as evaluated by micronucleus test (Tiuman et al., 2014).

In relation to anti- $T$. cruzi action, parthenolide showed an IC50 of $0.5 \mu \mathrm{g} / \mathrm{mL}$ against epimastigote forms and reduced the internalization of trypomastigotes forms of T. cruzi in LLMCK2 cells (51 and 96\% when the cells were treated at 2 and $4 \mu \mathrm{g} / \mathrm{mL}$, respectively). The compound also exhibited low toxicity against LLMCK2 cells with a SI of 6.4. Parthenolide induced severe alterations on the parasite, that included increase in the number of nucleus, vacuoles and reservosomes, mitochondrion swelling and the distortion of internal membranes (Izumi et al., 2008). The combinatory effects of parthenolide and benznidazole toward T. cruzi were also evaluated. This combination was synergistic against epimastigotes, while an additive effect was observed against trypomastigote forms (Pelizzaro-Rocha et al., 2010).

\section{COMPOUNDS FROM Tithonia diversifolia ARE ACTIVE AGAINST TRYPANOSOMATIDS}

Tithonia diversifolia (Hemsl.) A.Gray is a plant native of Mexico used in folk medicine that has anti-inflammatory, antimalarial, 
and antioxidant properties (Di Giacomo et al., 2015; Mabou Tagne et al., 2018). T. diversifolia dichloromethane leaf rinse extract (LRE) presents strong in vitro antileishmanial activity against promastigotes of L. braziliensis (IC50 $=1.5 \mu \mathrm{g} / \mathrm{mL}$ ). Eight sesquiterpene lactones were isolated from leaves extracts of this plant and seven showed anti-L. braziliensis promastigotes properties: $1 \beta, 2 \alpha$-epoxytagitinin C $(\mathrm{IC} 50=2.2 \mu \mathrm{g} / \mathrm{mL}$; SI> 22.7), tagitinin $\mathrm{F}(\mathrm{IC} 50=7.4 \mu \mathrm{g} / \mathrm{mL}$; SI $>6.7)$, tagitinin A $($ IC50 $=7.5 \mu \mathrm{g} / \mathrm{mL} ;$ SI $>6.6)$, Guaianolide 7 (IC50 $=$ $9.0 \mu \mathrm{g} / \mathrm{mL} ;$ SI $>5.5)$, tirotundin 3-O-methyl ether (IC50 = $13.7 \mu \mathrm{g} / \mathrm{mL} ;$ SI $>3.6$ ), tirotundin (IC50 $=8.7 \mu \mathrm{g} / \mathrm{mL} ;$ SI $=2.9)$, tagitinin $\mathrm{C}(\mathrm{IC} 50=3.2 \mu \mathrm{g} / \mathrm{mL} ;$ SI $=1.4)$. The five compounds with higher SI values were tested against amastigote forms, and the best results were found for tirotundin 3-O-methyl ether, tagitinin F, and guaianolide 7 (De Toledo et al., 2014).

\section{COMPOUNDS FROM Vernonia PLANTS ARE ACTIVE AGAINST TRYPANOSOMATIDS}

Plants from Vernonia genus are widely used in folk medicine (Toyang and Verpoorte, 2013) and some of them have been appointed as sources of bioactive compounds against trypanosomatids. For example, EOs from different parts of Vernonia brasiliana (L.) Druce were evaluated against trypanosomatids. Among the tested oils, the EO from flowers showed the best result toward L. amazonensis promastigotes, with an IC50 of $112 \mu \mathrm{g} / \mathrm{mL}$ and CC50 of $115 \mu \mathrm{g} / \mathrm{mL}$ and $391 \mu \mathrm{g} / \mathrm{mL}$ against Vero $(\mathrm{SI}=1)$ and RAW264.7 $(\mathrm{SI}=3)$ cells, respectively. Its major components were palmitic acid (8.30 $\%)$, (Z)-hex-2-en-1-ol (6.32\%), hexacosane (4.91\%), hexan1-ol (4.23\%), and (E)-hex-2-enal (4.04\%). Regarding the action against $T$. cruzi trypomastigotes, the root $\mathrm{EO}$ was the most active (IC50: $70 \mu \mathrm{g} / \mathrm{mL}$; SI = 3.1). The major compounds identified in this EO were modheph-2-ene (8.69\%), agurjunene (9.61\%), trans-caryophyllene (10.42\%), $\beta$-isocomene (10.26\%), and $\alpha$-isocomene (15.41\%) (Martins et al., 2015). Similarly, Moreira et al. (2017) studied the effect of the EO from leaves of Vernonia polyanthes Less. against promastigotes forms of L. infantum. The oil showed an IC50 of $19.4 \mu \mathrm{g} / \mathrm{mL}$, while zerumbone (one of its major compound) had an IC50 of $9.0 \mu \mathrm{g} / \mathrm{mL}$. The author did not report the SI value for zerumbone (Moreira et al., 2017).

Another plant from this genus with ethnopharmacological relevance is Vernonia scorpioides (Lam.) Pers. From this plant was extracted lupeol, that served as starting material for a semisynthetic approach in order to obtain antileishmanial and antitrypanosomal compounds. Among the derivatives, the best activity was observed for lup-20(29)-ene-diol with an IC50 of $12.4 \mu \mathrm{g} / \mathrm{mL}$ against $T$. cruzi amastigotes and a CC50 of $161.5 \mu \mathrm{g} / \mathrm{mL}$ toward THP-1 cells (SI = 12.94); this compound did not show antileishmanial action (Machado et al., 2018).

\section{XANTHANOLIDES FROM Xanthium PLANTS ARE ACTIVE AGAINST TRYPANOSOMATIDS}

Xanthanolides are bicyclic sesquiterpene lactones that have a five-membered g-butyrolactone ring fused to a seven-membered carbocycle. These compounds occur in only few species, and their richest sources are plants from the genus Xanthium (Vasas and Hohmann, 2011). Lavault et al. (2005) examined the leishmanicidal activities of seven xanthanolides isolated from Xanthium macrocarpum DC. Five xanthanolides were active against $L$. infantum and $L$. mexicana, being xanthinin the most active compound with an IC50 values of 3.6 and $4.7 \mu \mathrm{g} / \mathrm{mL}$ toward $L$. infantum and $L$. mexicana, respectively. The other isolated compounds (Xanthinosin, Xanthatin, 4Epiisoxanthanol, 4-Epixanthanol) exhibited IC50 values ranging from $24 \mu \mathrm{g} / \mathrm{mL}$ (4-Epiisoxanthanol) to $38 \mu \mathrm{g} / \mathrm{mL}$ (Xanthatin) against $L$. infantum, and from $35 \mu \mathrm{g} / \mathrm{mL}$ (4-Epixanthanol) to $44 \mu \mathrm{g} / \mathrm{mL}$ (Xanthinosin) toward L. mexicana. The authors did not report any data about the toxicity of these compounds (Lavault et al., 2005).

Bioactive xanthanolides were also obtained from Xanthium brasilicum Vell and tested against $T$. cruzi intracellular amastigotes $L$. donovani axenic amastigotes. Only three compounds showed anti-T. cruzi activity, however the low SI values (tested against L6 cells) demonstrated their small efficiency. The SI values were 1.97 for 8-Epixanthatin $1 \beta, 5 \beta$ epoxide, 1.15 for 8-Epixanthatin and 0.59 for Pungiolide A. On the other hand, all isolated xanthanolides were active against $L$. donovani and the best SI value were found for 8-Epixanthatin 1 $\beta, 5 \beta$-epoxide (SI $=36.94$ ),

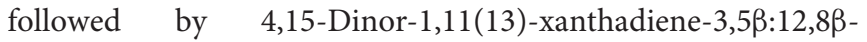
diolide $(\mathrm{SI}=14.22)$ and Xanthipungolide $(\mathrm{SI}>5.84)$ (Nour et al., 2009).

\section{$\alpha$-BISABOLOL AND $\alpha$-BISABOLOL-RICH ESSENTIAL OIL ARE ACTIVE AGAINST Leishmania SPP.}

The sesquiterpene $\alpha$-bisabolol has been pointed out as a promising agent against Leishmania spp. (Morales-Yuste et al., 2010; Rottini et al., 2015). This compound is found in essential oils from Asteraceae plants, such as Vanillosmopsis arborea Barker (Colares et al., 2013), Matricaria chamomilla (Andrade et al., 2016), and Matricaria recutita L (MoralesYuste et al., 2010; Hajaji et al., 2018). Colares et al. (2013) reported that the $V$. arborea EO and $\alpha$-bisabolol were active against $L$. amazonensis with IC50 values for promastigotes of 7.35 and $4.95 \mu \mathrm{g} / \mathrm{mL}$, respectively; and IC50 values for amastigotes of 12.58 and $10.70 \mu \mathrm{g} / \mathrm{mL}$. These agents also provoked low cytotoxic effects in J774.G8 macrophages (SI values around 20). In addition, accumulation of electrodense lipid inclusions vesicles was induced in promastigotes treated with $V$. arborea $\mathrm{EO}$ and $\alpha$-bisabolol (Colares et al., 2013). 
In turn, $M$. recutita EO showed an IC50 value of 10.8 and $10.4 \mu \mathrm{g} / \mathrm{mL}$ toward $L$. amazonensis and $L$. infantum promastigotes. Following, a bio-guided fractionation of the EO constituents resulted in the identification of $\alpha$-bisabolol as a major compound. $\alpha$-Bisabolol showed higher IC50 values for promastigotes (16.0 and $9.5 \mu \mathrm{g} / \mathrm{mL}$ for L. amazonensis and L. infantum, respectively). The efficacy of $\alpha$-bisabolol on amastigotes of both studied species was also assessed, and IC50 values of $5.9 \mu \mathrm{g} / \mathrm{mL}$ (L. amazonensis) and $4.8 \mu \mathrm{g} / \mathrm{mL}(L$. infantum) were obtained. The cytotoxic evaluation of $\alpha$-bisabolol was performed using J774A.1 macrophages and revealed SI values of 5.4 and 6.6 for L. amazonensis and L. infantum, respectively. The SI value for $L$. amazonensis was lower than that reported by Colares et al. (2013). The action of $\alpha$ bisabolol is associated to a damage in the parasite membrane, phosphatidylserine externalization, and to a decrease in the mitochondrial membrane potential and total ATP levels (Hajaji et al., 2018). Similar results were obtained by Corpas-López et al. (2016a) that showed that $\alpha$-bisabolol induced apoptosis in $L$. infantum, which is related to mitochondrial dysfunction and oxidative stress (Corpas-López et al., 2016a).

Moreover, $\alpha$-bisabolol was evaluated in a murine model of visceral leishmaniasis induced by $L$. infantum. The daily oral treatment with $\alpha$-bisabolol (at 50, 200, or 1,000 $\mathrm{mg} / \mathrm{kg}$ doses) started 28 days after L. infantum infection and continued for 14 days. The best results were seen for animals treated with $\alpha$-bisabolol at $200 \mathrm{mg} / \mathrm{kg}$, where the reduction on parasite levels on spleen and liver were 71.60 and $89.22 \%$, respectively. These results were even better than those observed for mice treated with meglumine antimoniate or the combination of meglumine antimoniate and $\alpha$-bisabolol (Corpas-López et al., 2015). $\alpha$-Bisabolol (in topical or oral treatment) was also shown to be effective in the treatment of cutaneous infection induced by $L$. tropica in hamsters (Corpas-López et al., 2016b). Recently, $\alpha$-bisabolol was useful for the treatment of naturally acquired canine leishmaniasis. In this elegant work, the dogs received oral doses of $\alpha$-bisabolol (30 $\mathrm{mg} / \mathrm{kg}$ ) during two series of 30 days, with 30 days of interval. The results showed that $\alpha$-bisabolol-treated dogs showed lower levels of parasite load (in bone marrow, lymph node and peripheral blood) than the dogs treated with meglumine antimoniate. $\alpha$ Bisabolol treatment also increased the expression of IFN- $\gamma$ (Corpas-López et al., 2018).

\section{OTHER COMPOUNDS FROM ASTERACEAE PLANTS WITH ACTIVITY AGAINST TRYPANOSOMATIDS}

Other compounds with activity against trypanosomatids have been isolated from the Asteraceae plants. Since the studies with these compounds only reported their isolation, they were grouped in this section. For example, the saponin Dasyscyphin C was isolated from Eclipta prostrata (L.) L. and showed activity against L. major promastigotes $(\mathrm{IC} 50=450 \mu \mathrm{g} / \mathrm{mL})$. The cytotoxicity of this saponin was not reported (Khanna et al., 2009). Similarly, Silva-Correa et al. (2018) identified an eudesman type sesquiterpen $[(4 \alpha S, \quad 5 R, 6 R, 8 \alpha R)-6-$ hidroxi-5, $8 \alpha$-dimetil-3-(1-metiletiliden) octahidronaftalen$2(1 \mathrm{H})$-ona)] as the active compound related to the leishmanicidal activity of Tessaria integrifolia Ruiz \& Pav in Mesocricetus auratus infected with Leishmania sp. (Silva-Correa et al., 2018).

Sosa et al. (2016) evaluated the in vitro activity against promastigotes of $L$. amazonensis and L. braziliensis of seventeen sesquiterpene lactones obtained from five plants belonging to the tribe Vernonieae (Vernonanthura pinguis (Griseb.) H.Rob., Vernonanthura nebularum (Cabrera) H.Rob., Eirmocephala megaphylla (Hieron.) H.Rob., Centratherum punctatum subsp. punctatum and Elephantopus mollis Kunth). These sesquiterpene lactones were from six structural groups: hirsutinolides, glaucolides, germacranolides, isogoyazensolides, goyazensolide, and germacradiendiolides. The authors reported that all compounds were able to inhibit the promastigotes forms of $L$. amazonensis and $L$. braziliensis, and these results confirm the leishmanicidal potential of sesquiterpene lactones (as seen for several plants discussed in this review; Barrera et al., 2013). Among the most active compounds were isodeoxyelephantopin, deoxyelephantopin, centratherin. The authors did not report any information about the toxicity of these compounds (Sosa et al., 2016).

Two bioactive germacranolides were also found in Neurolaena lobata (L.) R.Br. ex Cass. named Neurolenin B and Nerolenin C/D. They presented inhibitory activities toward L. mexicana promastigotes (IC50 values of 3.4 and $5.5 \mu \mathrm{g} / \mathrm{mL}$, respectively), $L$. braziliensis promastigotes (IC50 values of 98.5 and $188.6 \mu \mathrm{g} / \mathrm{mL}$, respectively) and epimastigotes (IC50 values of 6.3 and $11.7 \mu \mathrm{g} / \mathrm{mL}$, respectively) and trypomastigotes forms of T. cruzi (4.9 and $6.1 \mu \mathrm{g} / \mathrm{mL}$, respectively; Berger et al., 2001). Similarly, sesquiterpene lactones were isolated from Pseudelephantopus spiralis (Less.) Cronquist with activity against amastigotes forms of $L$. amazonensis: 8,13-diacetyl-piptocarphol (IC50 = $0.2 \mu \mathrm{M})$, 8-acetyl-13-O-ethyl-piptocarphol (IC50 = 0.37 $\mu \mathrm{M})$ and ursolic acid (IC50 $=0.99 \mu \mathrm{M}$; Odonne et al., 2011). In addition, three hirsutinolide-type sesquiterpenoids [diacetylpiptocarphol; piptocarphins A; $\left(1 \mathrm{~S}\left({ }^{*}\right), 4 \mathrm{R}\left({ }^{*}\right), 8 \mathrm{~S}\left({ }^{*}\right), 10 \mathrm{R}\left({ }^{*}\right)\right)$-1,4-epoxy-13ethoxy-1,8,10-trihydroxygermacra-5E,7(11)-dien-6,12-olide] with activity against promastigotes and axenic amastigotes of $L$. infantum were isolated from $P$. spiralis, however these compounds were found to be cytotoxic against VERO cells (Girardi et al., 2015).

Finally, it is important to highlight that those studies without data on the isolation/chemical composition of the extracts or their effects in vivo were not included in this manuscript. Examples of these studies are: Calendula officinalis L. against L. major promastigotes and amastigotes (Nikmehr et al., 2014); Echinacea purpurea (L.) Moench against L. donovani promastigotes (Canlas et al., 2010) and L. major in in vivo infection (Sarkari et al., 2017); Echinops kebericho Mesfin toward L. aethiopica and L. donovani promastigotes and amastigotes (Tariku et al., 2011); Gochnatia pulchra 
Cabrera against L. amazonensis (Lucarini et al., 2012, 2016); Waldheimia tomentosa (Decne.) Regel against L. major promastigotes and amastigotes (Bhatnagar et al., 2017); and Pulicaria gnaphalodes (Vent.) Boiss. toward L. major (Asghari et al., 2014).

\section{CONCLUSION}

Taken together, all these studies show that Asteraceae plants are interesting sources of compounds with inhibitory activity toward trypanosomatids. These compounds have the potential to improve the development of new effective agents against these neglected protozoan diseases. It is important to note that several of these compounds need to be evaluated with in vivo models. Furthermore, these papers provided scientific bases for the use of several plants with ethnopharmacological relevance in different countries.

\section{REFERENCES}

Abad, M. J., Bedoya, L. M., Apaza, L., and Bermejo, P. (2012). The artemisia L. Genus: a review of bioactive essential oils. Molecules 17, 2542-2566. doi: 10.3390/molecules17032542

Ali, S. I., Gopalakrishnan, B., and Venkatesalu, V. (2017). Pharmacognosy, phytochemistry and pharmacological properties of Achillea millefolium L.: a review. Phytother. Res. 31, 1140-1161. doi: 10.1002/ptr.5840

Alonso-Castro, A. J., Domínguez, F., Ruiz-Padilla, A. J., Campos-Xolalpa, N., Zapata-Morales, J. R., Carranza-Alvarez, C., et al. (2017). Medicinal plants from north and central america and the caribbean considered toxic for humans: the other side of the coin. Evid. Based Complement. Alternat. Med. 2017:9439868. doi: $10.1155 / 2017 / 9439868$

Aloui, Z., Messaoud, C., Haoues, M., Neffati, N., Bassoumi Jamoussi, I., Essafi-Benkhadir, K., et al. (2016). Asteraceae artemisia campestris and artemisia herba-alba essential oils trigger apoptosis and cell cycle arrest in leishmania infantum promastigotes. Evid. Based Complement. Alternat. Med. 2016:9147096. doi: 10.1155/2016/9147096

Althaus, J. B., Kaiser, M., Brun, R., and Schmidt, T. J. (2014). Antiprotozoal activity of Achillea ptarmica (Asteraceae) and its main alkamide constituents. Molecules 19, 6428-6438. doi: 10.3390/molecules19056428

Althaus, J. B., Malyszek, C., Kaiser, M., Brun, R., and Schmidt, T. J. (2017). Alkamides from Anacyclus pyrethrum L. and their in vitro antiprotozoal activity. Molecules 22:E796. doi: 10.3390/molecules22050796

Andrade, M. A., Azevedo, C. D., Motta, F. N., Santos, M. L., Silva, C. L., Santana, J. M., et al. (2016). Essential oils: in vitro activity against Leishmania amazonensis, cytotoxicity and chemical composition. BMC Complement. Altern. Med. 16:444. doi: 10.1186/s12906-016-1401-9

Aponte, J. C., Yang, H., Vaisberg, A. J., Castillo, D., Málaga, E., Verástegui, M., et al. (2010). Cytotoxic and anti-infective sesquiterpenes present in Plagiochila disticha (Plagiochilaceae) and Ambrosia peruviana (Asteraceae). Planta Med. 76, 705-707. doi: 10.1055/s-0029-1240681

Asghari, G., Zahabi, F., Eskandarian, A., Yousefi, H., and Asghari, M. (2014). Chemical composition and leishmanicidal activity of Pulicaria gnaphalodes essential oil. Research Journal of Pharmacognosy 1, 27-33.

Azizi, K., Shahidi-Hakak, F., Asgari, Q., Hatam, G. R., Fakoorziba, M. R., Miri, R., et al. (2016). In vitro efficacy of ethanolic extract of Artemisia absinthium (Asteraceae) against Leishmania major L. using cell sensitivity and flow cytometry assays. J. Parasit. Dis. 40, 735-740. doi: 10.1007/s12639-0 14-0569-5

Baldemir, A., Karaman, U., Ilgun, S., Kaçmaz, G., and Demirci, B. (2018). Antiparasitic efficacy of Artemisia ludoviciana Nutt. (Asteraceae) Essential Oil

\section{AUTHOR CONTRIBUTIONS}

$\mathrm{RM}$ and RS performed data collection and writing of the manuscript with support from LdS, TH, and AA. TH and MB contributed with the final version of the manuscript and with the important intellectual content of the study. LdS conceived the present study and design and implementation of the research and critical review of the manuscript regarding the important intellectual content of the study. AA contributed with the design of the research, data collection and supervised the work of RM and RS.

\section{FUNDING}

The authors would like to express their gratitude to Fundação de Amparo à Pesquisa e Desenvolvimento Científico do Maranhão (FAPEMA; UNIVERSAL-00998/16 and COOPI02860/16; FAPEMA UNIVERSAL-01354/18).

for Acanthamoeba castellanii, Leishmania infantum and Trichomonas vaginalis. Indian J. Pharmac. Educ. Res. 52, 416-425. doi: 10.5530/ijper.52.3.48

Barrera, P., Sülsen, V. P., Lozano, E., Rivera, M., Beer, M. F., Tonn, C., et al. (2013). Natural sesquiterpene lactones induce oxidative stress in Leishmania mexicana. Evid. Based Complement. Alternat. Med. 2013:163404. doi: 10.1155/2013/163404

Beer, M. F., Frank, F. M., Germán Elso, O., Ernesto Bivona, A., Cerny, N., Giberti, G., et al. (2016). Trypanocidal and leishmanicidal activities of flavonoids isolated from Stevia satureiifolia var. satureiifolia. Pharm. Biol. 54, 2188-2195. doi: 10.3109/13880209.2016.1150304

Berger, I., Passreiter, C. M., Cáceres, A., and Kubelka, W. (2001). Antiprotozoal activity of Neurolaena lobata. Phytother. Res. 15, 327-330. doi: 10.1002/ptr.782

Bermudez, J., Davies, C., Simonazzi, A., Real, J. P., and Palma, S. (2016). Current drug therapy and pharmaceutical challenges for Chagas disease. Acta Trop. 156, 1-16. doi: 10.1016/j.actatropica.2015.12.017

Bern, C. (2015). Chagas' Disease. N. Engl. J. Med. 373:1882. doi: 10.1056/NEJMra1410150

Bhatnagar, M., Avasthi, A. S., Singh, S., and Ghosal, S. (2017). Evaluation of antileishmanial and antibacterial activity of Waldheimia tomentosa (Asteraceae), and chemical profiling of the most bioactive fraction. Trop. J. Pharmac. Res. 16, 2169-2178. doi: 10.4314/tjpr.v16i9.18

Blum, J., Desjeux, P., Schwartz, E., Beck, B., and Hatz, C. (2004). Treatment of cutaneous leishmaniasis among travellers. J. Antimicrob. Chemother. 53, 158-166. doi: 10.1093/jac/dkh058

Bora, K. S., and Sharma, A. (2011). The genus Artemisia: a comprehensive review. Pharm. Biol. 49, 101-109. doi: 10.3109/13880209.2010.497815

Calvo, M. I., and Cavero, R. Y. (2015). Medicinal plants used for neurological and mental disorders in Navarra and their validation from official sources. $J$. Ethnopharmacol. 169, 263-268. doi: 10.1016/j.jep.2015.04.035

Calvo, M. I., and Cavero, R. Y. (2016). Medicinal plants used for ophthalmological problems in Navarra (Spain). J. Ethnopharmacol. 190, 212-218. doi: 10.1016/j.jep.2016.06.002

Canlas, J., Hudson, J. B., Sharma, M., and Nandan, D. (2010). Echinacea and trypanasomatid parasite interactions: growth-inhibitory and anti-inflammatory effects of Echinacea. Pharm. Biol. 48, 1047-1052. doi: 10.3109/13880200903483468

Carvalho, A. R. Jr., Diniz, R. M., Suarez, M. A. M., Figueiredo, C. S. S. E. S., Zagmignan, A., and Grisotto, M. A. G., et al. (2018). Use of some asteraceae plants for the treatment of wounds: from ethnopharmacological studies to scientific evidences. Front. Pharmacol. 9:784. doi: 10.3389/fphar.2018.00784

Cogo, J., Caleare Ade, O., Ueda-Nakamura, T., Filho, B. P., Ferreira, I. C., and Nakamura, C. V. (2012). Trypanocidal activity of guaianolide obtained from 
Tanacetum parthenium (L.) Schultz-Bip. and its combinational effect with benznidazole. Phytomedicine 20, 59-66. doi: 10.1016/j.phymed.2012.09.011

Colares, A. V., Almeida-Souza, F., Taniwaki, N. N., Souza Cda, S., Da Costa, J. G., Calabrese Kda, S., et al. (2013). In vitro antileishmanial activity of essential oil of vanillosmopsis arborea (Asteraceae) baker. Evid. Based Complement. Alternat. Med. 2013:727042. doi: 10.1155/2013/727042

Corpas-López, V., Merino-Espinosa, G., Acedo-Sánchez, C., Díaz-Sáez, V., Navarro-Moll, M. C., Morillas-Márquez, F., et al. (2018). Effectiveness of the sesquiterpene (-)-alpha-bisabolol in dogs with naturally acquired canine leishmaniosis: an exploratory clinical trial. Vet. Res. Commun. 42, 121-130. doi: 10.1007/s11259-018-9714-4

Corpas-López, V., Merino-Espinosa, G., Díaz-Sáez, V., Morillas-Márquez, F., Navarro-Moll, M. C., and Martín-Sánchez, J. (2016a). The sesquiterpene (-)alpha-bisabolol is active against the causative agents of Old World cutaneous leishmaniasis through the induction of mitochondrial-dependent apoptosis. Apoptosis 21, 1071-1081. doi: 10.1007/s10495-016-1282-x

Corpas-López, V., Merino-Espinosa, G., López-Viota, M., Gijón-Robles, P., Morillas-Mancilla, M. J., López-Viota, J., et al. (2016b). Topical treatment of leishmania tropica infection using (-)-alpha-bisabolol ointment in a hamster model: effectiveness and safety assessment. J. Nat. Prod. 79, 2403-2407. doi: $10.1021 /$ acs.jnatprod.6b00740

Corpas-López, V., Morillas-Márquez, F., Navarro-Moll, M. C., Merino-Espinosa, G., Díaz-Sáez, V., and Martín-Sánchez, J. (2015). (-)-alpha-Bisabolol, a promising oral compound for the treatment of visceral leishmaniasis. J. Nat. Prod. 78, 1202-1207. doi: 10.1021/np5008697

Cortes, S., Albuquerque, A., Cabral, L. I., Lopes, L., Campino, L., and Cristiano, M. L. (2015). In vitro susceptibility of leishmania infantum to artemisinin derivatives and selected trioxolanes. Antimicrob. Agents Chemother. 59, 5032-5035. doi: 10.1128/AAC.00298-15

Coura, J. R. (2015). Special issue on chagas disease. Mem. Inst. Oswaldo Cruz 110, 275-276. doi: 10.1590/0074-0276150001

Da Silva Filho, A. A., Pires Bueno, P. C., Gregorio, L. E., Andrade E Silva, M. L., Albuquerque, S., and Bastos, J. K. (2014). In-vitro trypanocidal activity evaluation of crude extract and isolated compounds from Baccharis dracunculifolia D.C. (Asteraceae). J. Pharm. Pharmacol. 56, 1195-1199. doi: 10.1211/0022357044067

Da Silva Filho, A. A., Resende, D. O., Fukui, M. J., Santos, F. F., Pauletti, P. M., Cunha, W. R., et al. (2019). In vitro antileishmanial, antiplasmodial and cytotoxic activities of phenolics and triterpenoids from Baccharis dracunculifolia D. C. (Asteraceae). Fitoterapia 80, 478-482. doi: 10.1016/j.fitote.2009.06.007

Da Silva, B. P., Cortez, D. A., Violin, T. Y., Dias Filho, B. P., Nakamura, C. V., Ueda-Nakamura, T., et al. (2010). Antileishmanial activity of a guaianolide from Tanacetum parthenium (L.) Schultz Bip. Parasitol. Int. 59, 643-646. doi: 10.1016/j.parint.2010.08.005

Da Silva, C. F., Batista Dda, G., De Araújo, J. S., Batista, M. M., Lionel, J., De Souza, E. M., et al. (2013). Activities of psilostachyin A and cynaropicrin against Trypanosoma cruzi in vitro and in vivo. Antimicrob. Agents Chemother. 57, 5307-5314. doi: 10.1128/AAC.00595-13

Das, S., Ghosh, S., De, A. K., and Bera, T. (2017). Oral delivery of ursolic acid-loaded nanostructured lipid carrier coated with chitosan oligosaccharides: Development, characterization, in vitro and in vivo assessment for the therapy of leishmaniasis. Int. J. Biol. Macromol. 102, 996-1008. doi: 10.1016/j.ijbiomac.2017.04.098

Davanço, M. G., Campos, M. L., Rosa, T. A., Padilha, E. C., Alzate, A. H., Rolim, L. A., et al. (2016). Benznidazole extended-release tablets for improved treatment of chagas disease: preclinical pharmacokinetic study. Antimicrob. Agents Chemother. 60, 2492-2498. doi: 10.1128/AAC.02506-15

De Mieri, M., Monteleone, G., Ismajili, I., Kaiser, M., and Hamburger, M. (2017). Antiprotozoal activity-based profiling of a dichloromethane extract from anthemis nobilis flowers. J. Nat. Prod. 80, 459-470. doi: 10.1021/acs.jnatprod.6b00980

De Toledo, J. S., Ambrósio, S. R., Borges, C. H., Manfrim, V., Cerri, D. G., Cruz, A. K., et al. (2014). In vitro leishmanicidal activities of sesquiterpene lactones from Tithonia diversifolia against Leishmania braziliensis promastigotes and amastigotes. Molecules 19, 6070-6079. doi: 10.3390/molecules190 56070
Di Giacomo, C., Vanella, L., Sorrenti, V., Santangelo, R., Barbagallo, I., Calabrese, G., et al. (2015). Effects of Tithonia diversifolia (Hemsl.) A. Gray extract on adipocyte differentiation of human mesenchymal stem cells. PLoS ONE 10:e0122320. doi: 10.1371/journal.pone.01 22320

Do Nascimento, A. M., Costa, F. C., Thiemann, O. H., and De Oliveira, D. C. (2007). Chromanones with leishmanicidal activity from Calea uniflora. $Z$ Naturforsch C 62, 353-356. doi: 10.1515/znc-2007-5-606

do Nascimento, A. M., Salvador, M. J., Candido, R. C., De Albuquerque, S., and De Oliveira, D. C. (2004). Trypanocidal and antifungal activities of p-hydroxyacetophenone derivatives from Calea uniflora (Heliantheae, Asteraceae). J. Pharm. Pharmacol. 56, 663-669. doi: 10.1211/0022357023231

Emami, S. A., Zamanai Taghizadeh Rabe, S., Ahi, A., and Mahmoudi, M. (2012). Inhibitory activity of eleven artemisia species from iran against Leishmania Major Parasites. Iran. J. Basic Med. Sci. 15, 807-811.

Esavand Heydari, F., Ghaffarifar, F., Soflaei, S., and Dalimi, A. (2013). Comparison between in vitro effects of aqueous extract of Artemisia seiberi and Artemisinin on Leishmania major. Jundishapur. J. Nat. Pharm. Prod. 8, 70-75. doi: 10.17795/jinpp-9513

Fattori, V., Zarpelon, A. C., Staurengo-Ferrari, L., Borghi, S. M., Zaninelli, T. H., Da Costa, F. B., et al. (2018). Budlein a, a sesquiterpene lactone from viguiera robusta, alleviates pain and inflammation in a model of acute gout arthritis in mice. Front. Pharmacol. 9:1076. doi: 10.3389/fphar.2018.01076

Feasey, N., Wansbrough-Jones, M., Mabey, D. C., and Solomon, A. W. (2010). Neglected tropical diseases. Br. Med. Bull. 93, 179-200. doi: 10.1093/bmb/ldp046

Frank, F. M., Ulloa, J., Cazorla, S. I., Maravilla, G., Malchiodi, E. L., Grau, A. et al. (2013). Trypanocidal activity of smallanthus sonchifolius: identification of active sesquiterpene lactones by bioassay-guided fractionation. Evid. Based Complement. Alternat. Med. 2013:627898. doi: 10.1155/2013/627898

García, M., Perera, W. H., Scull, R., and Monzote, L. (2011). Antileishmanial assessment of leaf extracts from Pluchea carolinensis, Pluchea odorata and Pluchea rosea. Asian Pac. J. Trop. Med. 4, 836-840. doi: 10.1016/S1995-7645(11)60204-6

García, M., Scull, R., Satyal, P., Setzer, W. N., and Monzote, L. (2017). Chemical characterization, antileishmanial activity, and cytotoxicity effects of the essential oil from leaves of Pluchea Carolinensis (Jacq.) G. Don. (Asteraceae). Phytother. Res. 31, 1419-1426. doi: 10.1002/ptr.5869

Ghaffarifar, F., Esavand Heydari, F., Dalimi, A., Hassan, Z. M., Delavari, M., and Mikaeiloo, H. (2015). Evaluation of apoptotic and antileishmanial activities of artemisinin on promastigotes and BALB/C mice infected with Leishmania major. Iran. J. Parasitol. 10, 258-267.

Ghosh, S., Kar, N., and Bera, T. (2016). Oleanolic acid loaded poly lactic coglycolic acid- vitamin E TPGS nanoparticles for the treatment of Leishmania donovani infected visceral leishmaniasis. Int. J. Biol. Macromol. 93, 961-970. doi: 10.1016/j.ijbiomac.2016.09.014

Girardi, C., Fabre, N., Paloque, L., Ramadani, A. P., Benoit-Vical, F., GonzálezAspajo, G., et al. (2015). Evaluation of antiplasmodial and antileishmanial activities of herbal medicine Pseudelephantopus spiralis (Less.) Cronquist and isolated hirsutinolide-type sesquiterpenoids. J. Ethnopharmacol. 170, 167-174. doi: 10.1016/j.jep.2015.05.014

Gómez-Estrada, H., Díaz-Castillo, F., Franco-Ospina, L., Mercado-Camargo, J., Guzmán-Ledezma, J., Medina, J. D., et al. (2011). Folk medicine in the northern coast of Colombia: an overview. J. Ethnobiol. Ethnomed. 7:27. doi: 10.1186/1746-4269-7-27

González, M. L., Joray, M. B., Laiolo, J., Crespo, M. I., Palacios, S. M., Ruiz, G. M., et al. (2018). Cytotoxic activity of extracts from plants of central argentina on sensitive and multidrug-resistant leukemia cells: isolation of an active principle from gaillardia megapotamica. Evid. Based Complement. Alternat. Med. 2018:9185935. doi: 10.1155/2018/9185935

Grecco Sdos, S., Félix, M. J., Lago, J. H., Pinto, E. G., Tempone, A. G., Romoff, P., et al. (2014). Anti-trypanosomal phenolic derivatives from Baccharis uncinella. Nat. Prod. Commun. 9, 171-173. doi: 10.1177/1934578X1400900210

Grecco Sdos, S., Reimão, J. Q., Tempone, A. G., Sartorelli, P., Cunha, R. L., Romoff, P., et al. (2012). In vitro antileishmanial and antitrypanosomal activities of flavanones from Baccharis retusa DC. (Asteraceae). Exp. Parasitol. 130, 141-145. doi: 10.1016/j.exppara.2011.11.002 
Grecco, S. S., Reimão, J. Q., Tempone, A. G., Sartorelli, P., Romoff, P., Ferreira, M. J., et al. (2010). Isolation of an antileishmanial and antitrypanosomal flavanone from the leaves of Baccharis retusa DC. (Asteraceae). Parasitol. Res. 106, 1245-1248. doi: 10.1007/s00436-010-1771-8

Hajaji, S., Sifaoui, I., López-Arencibia, A., Reyes-Batlle, M., Jiménez, I. A., Bazzocchi, I. L., et al. (2018). Leishmanicidal activity of alpha-bisabolol from Tunisian chamomile essential oil. Parasitol. Res. 117, 2855-2867. doi: 10.1007/s00436-018-5975-7

Harel, D., Khalid, S. A., Kaiser, M., Brun, R., Wünsch, B., and Schmidt, T. J. (2011). Encecalol angelate, an unstable chromene from Ageratum conyzoides L.: total synthesis and investigation of its antiprotozoal activity. J. Ethnopharmacol. 137, 620-625. doi: 10.1016/j.jep.2011.06.015

Islamuddin, M., Chouhan, G., Tyagi, M., Abdin, M. Z., Sahal, D., and Afrin, F. (2014). Leishmanicidal activities of Artemisia annua leaf essential oil against Visceral Leishmaniasis. Front. Microbiol. 5:626. doi: 10.3389/fmicb.2014.00626

Islamuddin, M., Chouhan, G., Want, M. Y., Tyagi, M., Abdin, M. Z., Sahal, D., et al. (2015). Corrigendum: Leishmanicidal activities of Artemisia annua leaf essential oil against Visceral Leishmaniasis. Front. Microbiol. 6:1015. doi: $10.3389 /$ fmicb.2015.01015

Islamuddin, M., Farooque, A., Dwarakanath, B. S., Sahal, D., and Afrin, F. (2012). Extracts of Artemisia annua leaves and seeds mediate programmed cell death in Leishmania donovani. J. Med. Microbiol. 61, 1709-1718. doi: 10.1099/jmm.0.049387-0

Izumi, E., Morello, L. G., Ueda-Nakamura, T., Yamada-Ogatta, S. F., Filho, B. P., Cortez, D. A., et al. (2008). Trypanosoma cruzi: antiprotozoal activity of parthenolide obtained from Tanacetum parthenium (L.) Schultz Bip. (Asteraceae, Compositae) against epimastigote and amastigote forms. Exp. Parasitol. 118, 324-330. doi: 10.1016/j.exppara.2007.08.015

Jesus, J. A., Fragoso, T. N., Yamamoto, E. S., Laurenti, M. D., Silva, M. S., Ferreira, A. F., et al. (2017). Therapeutic effect of ursolic acid in experimental visceral leishmaniasis. Int. J. Parasitol. Drugs Drug Resist. 7, 1-11. doi: 10.1016/j.ijpddr.2016.12.002

Karioti, A., Skaltsa, H., Kaiser, M., and Tasdemir, D. (2009). Trypanocidal, leishmanicidal and cytotoxic effects of anthecotulide-type linear sesquiterpene lactones from Anthemis auriculata. Phytomedicine 16, 783-787. doi: 10.1016/j.phymed.2008.12.008

Khanna, V. G., Kannabiran, K., and Getti, G. (2009). Leishmanicidal activity of saponins isolated from the leaves of Eclipta prostrata and Gymnema sylvestre. Indian J. Pharmacol. 41, 32-35. doi: 10.4103/0253-7613.48891

Kimani, N. M., Matasyoh, J. C., Kaiser, M., Brun, R., and Schmidt, T. J. (2017). Anti-trypanosomatid elemanolide sesquiterpene lactones from vernonia lasiopus O. Hoffm. Molecules 22:E597. doi: 10.3390/molecules22040597

Laadraoui, J., Aboufatima, R., El Gabbas, Z., Ferehan, H., Bezza, K., Ait Laaradia, M., et al. (2018). Effect of Artemisia herba-alba consumption during pregnancy on fertility, morphological and behaviors of mice offspring. J. Ethnopharmacol. 226, 105-110. doi: 10.1016/j.jep.2018.08.017

Laurella, L. C., Cerny, N., Bivona, A. E., Sanchez Alberti, A., Giberti, G., Malchiodi, E. L., et al. (2017). Assessment of sesquiterpene lactones isolated from Mikania plants species for their potential efficacy against Trypanosoma cruzi and Leishmania sp. PLoS Negl. Trop. Dis. 11:e0005929. doi: 10.1371/journal.pntd.0005929

Laurella, L. C., Frank, F. M., Sarquiz, A., Alonso, M. R., Giberti, G., Cavallaro, L., et al. (2012). In vitro evaluation of antiprotozoal and antiviral activities of extracts from Argentinean Mikania species. ScientificWorldJournal. 2012:121253. doi: 10.1100/2012/121253

Lavault, M., Landreau, A., Larcher, G., Bouchara, J. P., Pagniez, F., Le Pape, P., et al. (2005). Antileishmanial and antifungal activities of xanthanolides isolated from Xanthium macrocarpum. Fitoterapia 76, 363-366. doi: 10.1016/j.fitote.2005.03.019

Li, Y., Li, J., Li, Y., Wang, X. X., and Cao, A. C. (2013). Antimicrobial constituents of the leaves of Mikania micrantha H. B. K. PLoS ONE 8:e76725. doi: 10.1371/journal.pone.0076725

Lima, T. C., Santos, A. D. C., Costa, D. T. M., Souza, R. J., Barison, A., Steindel, M., et al. (2015). Chromenes from leaves of Calea pinnatifida and evaluation of their leishmanicidal activity. Rev. Bras. Farmacogn. 25, 7-10. doi: 10.1016/j.bjp.2015.01.004

Lima, T. C., Souza, R. D. J., Moraes, M. H., Steindel, M., and Biavatti, M. W. (2017). A new furanoheliangolide sesquiterpene lactone from calea pinnatifida
(R. Br.) Less. (Asteraceae) and evaluation of its trypanocidal and leishmanicidal activities. J. Braz. Chem. Soc. 28, 367-375. doi: 10.5935/0103-5053.20160186

Lima, T. C., Souza, R. J., Santos, A. D., Moraes, M. H., Biondo, N. E., Barison, A., et al. (2016). Evaluation of leishmanicidal and trypanocidal activities of phenolic compounds from Calea uniflora Less. Nat. Prod. Res. 30, 551-557. doi: 10.1080/14786419.2015.1030740

Lucarini, R., Magalhaes, L. G., Rodrigues, V., Souza, J. M., Tozatti, M. G., Pires, R. H., et al. (2016). Antiprotozal and antihelminthic evaluation of the hydroalcoholic extract, fractions and compounds of gochnatia pulchra. Latin Am. J. Pharmacy 35, 762-767.

Lucarini, R., Salloum, A., Rezende, K., Esperandim, V., Ferreira, D., Magalhães, L., et al. (2012). Antileishymanicidal acvity of Gochnatia pulchra. Planta Med. 78:PI416. doi: 10.1055/s-0032-1321103

Mabou Tagne, A., Marino, F., and Cosentino, M. (2018). Tithonia diversifolia (Hemsl.) A. Gray as a medicinal plant: a comprehensive review of its ethnopharmacology, phytochemistry, pharmacotoxicology and clinical relevance. J. Ethnopharmacol. 220, 94-116. doi: 10.1016/j.jep.2018.03.025

Machado, V. R., Sandjo, L. P., Pinheiro, G. L., Moraes, M. H., Steindel, M., Pizzolatti, M. G., et al. (2018). Synthesis of lupeol derivatives and their antileishmanial and antitrypanosomal activities. Nat. Prod. Res. 32, 275-281. doi: 10.1080/14786419.2017.1353982

Manouze, H., Bouchatta, O., Gadhi, A. C., Bennis, M., Sokar, Z., and BaM'hamed, S. (2017). Anti-inflammatory, antinociceptive, and antioxidant activities of methanol and aqueous extracts of anacyclus pyrethrum roots. Front. Pharmacol. 8:598. doi: 10.3389/fphar.2017.00598

Martins, M. M., De Aquino, F. J. T., De Oliveira, A., Do Nascimento, E. A., Chang, R., Borges, M. S., et al. (2015). Chemical composition, antimicrobial and antiprotozoal activity of essential oils from vernonia brasiliana (Less) druce (Asteraceae). J. Essent. Oil Bear. Plants 18, 561-569. doi: 10.1080/0972060X.2014.895683

Martins-Melo, F. R., Ramos, A. N. Jr., Alencar, C. H., and Heukelbach, J. (2016). Mortality from neglected tropical diseases in Brazil, 20002011. Bull. World Health Organ. 94, 103-110. doi: 10.2471/BLT.15.1 52363

Melo, T. S., Gattass, C. R., Soares, D. C., Cunha, M. R., Ferreira, C., Tavares, M. T., et al. (2016). Oleanolic acid (OA) as an antileishmanial agent: Biological evaluation and in silico mechanistic insights. Parasitol. Int. 65, 227-237. doi: 10.1016/j.parint.2016.01.001

Mesa, L. E., Vasquez, D., Lutgen, P., Vélez, I. D., Restrepo, A. M., Ortiz, I., et al. (2017). In vitro and in vivo antileishmanial activity of Artemisia annua L. leaf powder and its potential usefulness in the treatment of uncomplicated cutaneous leishmaniasis in humans. Rev. Soc. Bras. Med. Trop. 50, 52-60. doi: 10.1590/0037-8682-0457-2016

Mirzaei, F., Bafghi, A. F., Mohaghegh, M. A., Jaliani, H. Z., Faridnia, R., and Kalani, H. (2016). In vitro anti-leishmanial activity of Satureja hortensis and Artemisia dracunculus extracts on Leishmania major promastigotes. J. Parasit. Dis. 40, 1571-1574. doi: 10.1007/s12639-015-0730-9

Montrieux, E., Perera, W. H., García, M., Maes, L., Cos, P., and Monzote, L. (2014). In vitro and in vivo activity of major constituents from Pluchea carolinensis against Leishmania amazonensis. Parasitol. Res. 113, 2925-2932. doi: 10.1007/s00436-014-3954-1

Monzote, L., Piñón, A., Sculli, R., and Setzer, W. N. (2014). Chemistry and leishmanicidal activity of the essential oil from Artemisia absinthium from Cuba. Nat. Prod. Commun. 9, 1799-1804. doi: 10.1177/1934578 X1400901236

Morais, T. R., Romoff, P., Fávero, O. A., Reimão, J. Q., Lourenço, W. C., Tempone, A. G., et al. (2012). Anti-malarial, anti-trypanosomal, and antileishmanial activities of jacaranone isolated from Pentacalia desiderabilis (Vell.) Cuatrec. (Asteraceae). Parasitol. Res. 110, 95-101. doi: 10.1007/s00436-0112454-9

Morales-Yuste, M., Morillas-Márquez, F., Martín-Sánchez, J., Valero-López, A., and Navarro-Moll, M. C. (2010). Activity of (-)alpha-bisabolol against Leishmania infantum promastigotes. Phytomedicine 17, 279-281. doi: 10.1016/j.phymed.2009.05.019

Moreira, R. R. D., Martins, G. Z., Varandas, R., Cogo, J., Perego, C. H., Roncoli, G., et al. (2017). Composition and leishmanicidal activity of the essential oil of Vernonia polyanthes Less (Asteraceae). Nat. Prod. Res. 31, 2905-2908. doi: 10.1080/14786419.2017.1299723 
Naß, J., and Efferth, T. (2018). The activity of Artemisia spp. and their constituents against Trypanosomiasis. Phytomedicine 47, 184-191. doi: 10.1016/j.phymed.2018.06.002

Nikmehr, B., Ghaznavi, H., Rahbar, A., Sadr, S., and Mehrzadi, S. (2014). In vitro anti-leishmanial activity of methanolic extracts of Calendula officinalis flowers, Datura stramonium seeds, and Salvia officinalis leaves. Chin. J. Nat. Med. 12, 423-427. doi: 10.1016/S1875-5364(14)60066-2

Nogueira, M. S., Da Costa, F. B., Brun, R., Kaiser, M., and Schmidt, T. J. (2016). ent-pimarane and ent-kaurane diterpenes from aldama discolor (asteraceae) and their antiprotozoal activity. Molecules 21:E1237. doi: 10.3390/molecules21091237

Nour, A. M., Khalid, S. A., Kaiser, M., Brun, R., Abdalla, W. E., and Schmidt, T. J. (2010). The antiprotozoal activity of methylated flavonoids from Ageratum conyzoides L. J. Ethnopharmacol. 129, 127-130. doi: 10.1016/j.jep.2010. 02.015

Nour, A. M., Khalid, S. A., Kaiser, M., Brun, R., Abdallah, W. E., and Schmidt, T. J. (2009). The antiprotozoal activity of sixteen asteraceae species native to Sudan and bioactivity-guided isolation of xanthanolides from Xanthium brasilicum. Planta Med. 75, 1363-1368. doi: 10.1055/s-0029-1185676

Odonne, G., Herbette, G., Eparvier, V., Bourdy, G., Rojas, R., Sauvain, M., et al. (2011). Antileishmanial sesquiterpene lactones from Pseudelephantopus spicatus, a traditional remedy from the Chayahuita Amerindians (Peru). Part III. J. Ethnopharmacol. 137, 875-879. doi: 10.1016/j.jep.2011. 07.008

Okunade, A. L. (2002). Ageratum conyzoides L. (Asteraceae). Fitoterapia 73, 1-16. doi: 10.1016/S0367-326X(01)00364-1

Olennikov, D. N., Chirikova, N. K., Kashchenko, N. I., Nikolaev, V. M., Kim, S. W., and Vennos, C. (2018). Bioactive phenolics of the genus artemisia (Asteraceae): HPLC-DAD-ESI-TQ-MS/MS profile of the siberian species and their inhibitory potential against alpha-amylase and alpha-glucosidase. Front. Pharmacol. 9:756. doi: 10.3389/fphar.2018.00756

Pahuja, M., Mehla, J., Reeta, K. H., Joshi, S., and Gupta, Y. K. (2012). Root extract of Anacyclus pyrethrum ameliorates seizures, seizure-induced oxidative stress and cognitive impairment in experimental animals. Epilepsy Res. 98, 157-165. doi: 10.1016/j.eplepsyres.2011.09.006

Palmeiro-Roldán, R., Fonseca-Berzal, C., Gómez-Barrio, A., Arán, V. J., Escario, J. A., Torrado-Durán, S., et al. (2014). Development of novel benznidazole formulations: physicochemical characterization and in vivo evaluation on parasitemia reduction in Chagas disease. Int. J. Pharm. 472, 110-117. doi: 10.1016/j.ijpharm.2014.06.015

Parreira, N. A., Magalhães, L. G., Morais, D. R., Caixeta, S. C., De Sousa, J. P., Bastos, J. K., et al. (2010). Antiprotozoal, schistosomicidal, and antimicrobial activities of the essential oil from the leaves of Baccharis dracunculifolia. Chem. Biodivers. 7, 993-1001. doi: 10.1002/cbdv.2009 00292

Passero, L. F., Bonfim-Melo, A., Corbett, C. E., Laurenti, M. D., Toyama, M. H., De Toyama, D. O., et al. (2011). Anti-leishmanial effects of purified compounds from aerial parts of Baccharis uncinella C. DC. (Asteraceae). Parasitol. Res. 108, 529-536. doi: 10.1007/s00436-010-2091-8

Pelizzaro-Rocha, K. J., Tiuman, T. S., Izumi, E., Ueda-Nakamura, T., Dias Filho, B. P., and Nakamura, C. V. (2010). Synergistic effects of parthenolide and benznidazole on Trypanosoma cruzi. Phytomedicine 18, 36-39. doi: 10.1016/j.phymed.2010.09.005

Pereira, C. G., Barreira, L., Bijttebier, S., Pieters, L., Marques, C., Santos, T. F., et al. (2018). Health promoting potential of herbal teas and tinctures from Artemisia campestris subsp. maritima: from traditional remedies to prospective products. Sci. Rep. 8:4689. doi: 10.1038/s41598-018-23038-6

Pertino, M. W., Vega, C., Rolón, M., Coronel, C., Rojas De Arias, A., and Schmeda-Hirschmann, G. (2017). Antiprotozoal activity of triazole derivatives of dehydroabietic acid and oleanolic acid. Molecules 22:E369. doi: 10.3390/molecules22030369

Puente, V., Laurella, L. C., Spina, R. M., Lozano, E., Martino, V. S., Sosa, M. A., et al. (2018). Primary targets of the sesquiterpene lactone deoxymikanolide on Trypanosoma cruzi. Phytomedicine 56, 27-34. doi: 10.1016/j.phymed.2018.10.015

Ramos, L. S., Cardoso, P. S., Freitas, M. D., Paghan, R., Borges, M. S., Citadini-Zanette, V., et al. (2016). Popular medicinal uses of Calea uniflora Less. (Asteraceae) and its contribution to the study of Brazilian medicinal plants. An. Acad. Bras. Cienc. 88, 2319-2330. doi: 10.1590/0001-3765201620 160120

Reithinger, R., Brooker, S., and Kolaczinski, J. H. (2007a). Visceral leishmaniasis in eastern Africa-current status. Trans. R. Soc. Trop. Med. Hyg. 101, 1169-1170. doi: 10.1016/j.trstmh.2007.06.001

Reithinger, R., Dujardin, J. C., Louzir, H., Pirmez, C., Alexander, B., and Brooker, S. (2007b). Cutaneous leishmaniasis. Lancet Infect. Dis. 7, 581-596. doi: 10.1016/S1473-3099(07)70209-8

Rezaei, R., Hazrati Tappeh, K., Seyyedi, S., and Mikaili, P. (2017). The Antileishmanial efficacy of artemisia dracunculus ethanolic extract in vitro and its effects on IFN-gamma and IL-4 response. Iran. J. Parasitol. 12, 398-407.

Rigat, M., Bonet, M. À., Garcia, S., Garnatje, T., and Vallès, J. (2009). Ethnobotany of food plants in the high river Ter valley (Pyrenees, Catalonia, Iberian Peninsula): non-crop food vascular plants and crop food plants with medicinal properties. Ecol. Food Nutr. 48, 303-326. doi: 10.1080/03670240903022320

Rodrigues, K. C., Chibli, L. A., Santos, B. C., Temponi, V. S., Pinto, N. C., Scio, E., et al. (2016). Evidence of bioactive compounds from vernonia polyanthes leaves with topical anti-inflammatory potential. Int. J. Mol. Sci. 17:E1929. doi: 10.3390/ijms17121929

Rottini, M. M., Amaral, A. C., Ferreira, J. L., Silva, J. R., Taniwaki, N. N., Souza Cda, S., et al. (2015). In vitro evaluation of (-)alpha-bisabolol as a promising agent against Leishmania amazonensis. Exp. Parasitol. 148, 66-72. doi: 10.1016/j.exppara.2014.10.001

Sarkari, B., Mohseni, M., Moein, M. R., Shahriarirad, R., and Asgari, Q. (2017). Effect of hydroalcoholic extract of Echinacea purpurea in combination with meglumine antimoniate on treatment of Leishmania major-induced cutaneous leishmaniasis in $\mathrm{BALB} / \mathrm{c}$ mice. Int. J. Appl. Basic Med. Res. 7, 53-56. doi: 10.4103/2229-516X.198524

Sen, R., Bandyopadhyay, S., Dutta, A., Mandal, G., Ganguly, S., Saha, P., et al. (2007). Artemisinin triggers induction of cell-cycle arrest and apoptosis in Leishmania donovani promastigotes. J. Med. Microbiol. 56, 1213-1218. doi: 10.1099/jmm.0.47364-0

Sen, R., Saha, P., Sarkar, A., Ganguly, S., and Chatterjee, M. (2010). Iron enhances generation of free radicals by Artemisinin causing a caspase-independent, apoptotic death in Leishmania donovani promastigotes. Free Radic. Res. 44, 1289-1295. doi: 10.3109/10715762.2010.498475

Sharma, J., Gairola, S., Sharma, Y. P., and Gaur, R. D. (2014). Ethnomedicinal plants used to treat skin diseases by Tharu community of district Udham Singh Nagar, Uttarakhand, India. J. Ethnopharmacol. 158 (Pt A), 140-206. doi: 10.1016/j.jep.2014.10.004

Sifaoui, I., López-Arencibia, A., Martín-Navarro, C. M., Reyes-Batlle, M., Mejri, M., Valladares, B., et al. (2017). Selective activity of oleanolic and maslinic acids on the amastigote form of Leishmania Spp. Iran J. Pharm. Res. 16, 1190-1193.

Sifaoui, I., López-Arencibia, A., Martín-Navarro, C. M., Ticona, J. C., ReyesBatlle, M., Mejri, M., et al. (2014). In vitro effects of triterpenic acids from olive leaf extracts on the mitochondrial membrane potential of promastigote stage of Leishmania spp. Phytomedicine 21, 1689-1694. doi: 10.1016/j.phymed.2014.08.004

Silva-Correa, C. R., Cruzado-Razco, J. L., González-Blas, M. V., García-Armas, J. M., Ruiz-Reyes, S. G., Villarreal-La Torre, V. E., et al. (2018). [Identification and structural determination of a sesquiterpene of Tessaria integrifolia Ruiz \& Pav. leaves and evaluation of its leishmanicidal activity]. Rev. Peru. Med. Exp. Salud. Publica 35, 221-227. doi: 10.17843/rpmesp.2018.352.3140

Sosa, A. M., Amaya, S., Salamanca Capusiri, E., Gilabert, M., Bardón, A., Giménez, A., et al. (2016). Active sesquiterpene lactones against Leishmania amazonensis and Leishmania braziliensis. Nat. Prod. Res. 30, 2611-2615. doi: 10.1080/14786419.2015.1126260

Sülsen, V., Barrera, P., Muschietti, L., Martino, V., and Sosa, M. (2010). Antiproliferative effect and ultrastructural alterations induced by psilostachyin on Trypanosoma cruzi. Molecules 15, 545-553. doi: 10.3390/molecules 15010545

Sülsen, V., Güida, C., Coussio, J., Paveto, C., Muschietti, L., and Martino, V. (2006). In vitro evaluation of trypanocidal activity in plants used in Argentine traditional medicine. Parasitol. Res. 98, 370-374. doi: 10.1007/s00436-005-0060-4

Sülsen, V. P., Cazorla, S. I., Frank, F. M., Laurella, L. C., Muschietti, L. V., Catalán, C. A., et al. (2013). Natural terpenoids from Ambrosia species are active in vitro and in vivo against human pathogenic trypanosomatids. PLoS Negl. Trop. Dis. 7:e2494. doi: 10.1371/journal.pntd.0002494 
Sülsen, V. P., Cazorla, S. I., Frank, F. M., Redko, F. C., Anesini, C. A., Coussio, J. D., et al. (2007). Trypanocidal and leishmanicidal activities of flavonoids from Argentine medicinal plants. Am. J. Trop. Med. Hyg. 77, 654-659. doi: 10.4269/ajtmh.2007.77.654

Sülsen, V. P., Frank, F. M., Cazorla, S. I., Anesini, C. A., Malchiodi, E. L., Freixa, B., et al. (2008). Trypanocidal and leishmanicidal activities of sesquiterpene lactones from Ambrosia tenuifolia Sprengel (Asteraceae). Antimicrob. Agents Chemother. 52, 2415-2419. doi: 10.1128/AAC.01630-07

Sülsen, V. P., Frank, F. M., Cazorla, S. I., Barrera, P., Freixa, B., Vila, R., et al. (2011). Psilostachyin C: a natural compound with trypanocidal activity. Int. J. Antimicrob. Agents 37, 536-543. doi: 10.1016/j.ijantimicag.2011.02.003

Sülsen, V. P., Puente, V., Papademetrio, D., Batlle, A., Martino, V. S., Frank, F. M., et al. (2016). Mode of action of the sesquiterpene lactones psilostachyin and psilostachyin C on Trypanosoma cruzi. PLoS ONE 11:e0150526. doi: 10.1371/journal.pone.0150526

Takahashi, H. T., Britta, E. A., Longhini, R., Ueda-Nakamura, T., Palazzo De Mello, J. C., and Nakamura, C. V. (2013). Antileishmanial activity of 5methyl-2,2': 5',2" -terthiophene isolated from Porophyllum ruderale is related to mitochondrial dysfunction in Leishmania amazonensis. Planta Med. 79, 330-333. doi: 10.1055/s-0032-1328258

Takahashi, H. T., Novello, C. R., Ueda-Nakamura, T., Filho, B. P., Palazzo De Mello, J. C., and Nakamura, C. V. (2011). Thiophene derivatives with antileishmanial activity isolated from aerial parts of Porophyllum ruderale (Jacq.) Cass. Molecules 16, 3469-3478. doi: 10.3390/molecules 160 53469

Tamargo, B., Monzote, L., Piñón, A., Machín, L., García, M., Scull, R., et al. (2017). In vitro and in vivo evaluation of essential oil from Artemisia absinthium $\mathrm{L}$. Formulated in nanocochleates against cutaneous leishmaniasis. Medicines 4:38. doi: 10.3390/medicines4020038

Tariku, Y., Hymete, A., Hailu, A., and Rohloff, J. (2010). Essential-oil composition, antileishmanial, and toxicity study of Artemisia abyssinica and Satureja punctata ssp. punctata from Ethiopia. Chem Biodivers 7, 1009-1018. doi: 10.1002/cbdv.200900375

Tariku, Y., Hymete, A., Hailu, A., and Rohloff, J. (2011). In vitro evaluation of antileishmanial activity and toxicity of essential oils of Artemisia absinthium and Echinops kebericho. Chem. Biodivers. 8, 614-623. doi: $10.1002 /$ cbdv.201000331

Teixeira, T. L., Teixeira, S. C., Da Silva, C. V., and De Souza, M. A. (2014). Potential therapeutic use of herbal extracts in trypanosomiasis. Pathog. Glob. Health 108, 30-36. doi: 10.1179/2047773213Y.0000000120

Tiuman, T. S., Ueda-Nakamura, T., Alonso, A., and Nakamura, C. V. (2014). Cell death in amastigote forms of Leishmania amazonensis induced by parthenolide. BMC Microbiol. 14:152. doi: 10.1186/1471-2180-14-152

Tiuman, T. S., Ueda-Nakamura, T., Garcia Cortez, D. A., Dias Filho, B. P., Morgado-Díaz, J. A., De Souza, W., et al. (2005). Antileishmanial activity of parthenolide, a sesquiterpene lactone isolated from Tanacetum parthenium. Antimicrob. Agents Chemother. 49, 176-182. doi: 10.1128/AAC.49.11.176-182.2005

Tiwari, K., and Dubey, V. K. (2018). Leishmania donovani asparaginase variants exhibit cytosolic localization. Int. J. Biol. Macromol. 114, 35-39. doi: 10.1016/j.ijbiomac.2018.03.071

Tiwari, N., Gedda, M. R., Tiwari, V. K., Singh, S. P., and Singh, R. K. (2018). Limitations of current therapeutic options, possible drug targets and scope of natural products in control of leishmaniasis. Mini Rev. Med. Chem. 18, 26-41. doi: $10.2174 / 1389557517666170425105129$

Toyang, N. J., and Verpoorte, R. (2013). A review of the medicinal potentials of plants of the genus Vernonia (Asteraceae). J. Ethnopharmacol. 146, 681-723. doi: 10.1016/j.jep.2013.01.040

Ueno, A. K., Barcellos, A. F., Costa-Silva, T. A., Mesquita, J. T., Ferreira, D. D., Tempone, A. G., et al. (2018). Antitrypanosomal activity and evaluation of the mechanism of action of diterpenes from aerial parts of Baccharis retusa (Asteraceae). Fitoterapia 125, 55-58. doi: 10.1016/j.fitote.2017.12.016
Ullah, N., Ahmad, I., Ahmad, N., and Fozia (2017). In vitro antimicrobial, antiprotozoal activities and heavy metals toxicity of different parts of Ballota pseudodictamnus (L.) Benth. Pak. J. Pharm. Sci. 30, 2203-2209.

Ulloa, J. L., Spina, R., Casasco, A., Petray, P. B., Martino, V., Sosa, M. A. et al. (2017). Germacranolide-type sesquiterpene lactones from Smallanthus sonchifolius with promising activity against Leishmania mexicana and Trypanosoma cruzi. Parasit. Vectors 10:567. doi: 10.1186/s13071-017-2509-6

Van Der Kooy, F., and Sullivan, S. E. (2013). The complexity of medicinal plants: the traditional Artemisia annua formulation, current status and future perspectives. J. Ethnopharmacol. 150, 1-13. doi: 10.1016/j.jep.20 13.08.021

Varela, J., Lavaggi, M. L., Cabrera, M., Rodríguez, A., Miño, P., Chiriboga, X., et al. (2012). Bioactive-guided identification of labdane diterpenoids from aerial parts of Aristeguietia glutinosa as anti-Trypanosoma cruzi agents. Nat. Prod. Commun. 7, 1139-1142. doi: 10.1177/1934578X1200700907

Varela, J., Serna, E., Torres, S., Yaluff, G., De Bilbao, N. I., Miño, P., et al. (2014). In vivo anti-Trypanosoma cruzi activity of hydro-ethanolic extract and isolated active principles from Aristeguietia glutinosa and mechanism of action studies. Molecules 19, 8488-8502. doi: 10.3390/molecules 190 68488

Vasas, A., and Hohmann, J. (2011). Xanthane sesquiterpenoids: structure, synthesis and biological activity. Nat. Prod. Rep. 28, 824-842. doi: 10.1039/c0n p00011f

Want, M. Y., Islammudin, M., Chouhan, G., Ozbak, H. A., Hemeg, H. A., Chattopadhyay, A. P., et al. (2017). Nanoliposomal artemisinin for the treatment of murine visceral leishmaniasis. Int. J. Nanomedicine 12, 2189-2204. doi: $10.2147 /$ IJN.S106548

Want, M. Y., Islamuddin, M., Chouhan, G., Dasgupta, A. K., Chattopadhyay, A. P., and Afrin, F. (2014). A new approach for the delivery of artemisinin: formulation, characterization, and ex-vivo antileishmanial studies. J. Colloid Interface Sci. 432, 258-269. doi: 10.1016/j.jcis.2014. 06.035

Want, M. Y., Islamuddin, M., Chouhan, G., Ozbak, H. A., Hemeg, H. A., Dasgupta, A. K., et al. (2015). Therapeutic efficacy of artemisinin-loaded nanoparticles in experimental visceral leishmaniasis. Colloids Surf. B Biointerfaces 130, 215-221. doi: 10.1016/j.colsurfb.2015.04.013

WHO (2013). WHO. Available online at: http://www.who.int/about/es/ (accessed June 14, 2018)

WHO (2016). WHO. Available onlien at: http://www.who.int/about/es/ (accessed June 14, 2018)

Yamamoto, E. S., Campos, B. L., Jesus, J. A., Laurenti, M. D., Ribeiro, S. P., Kallás, E. G., et al. (2015). The effect of ursolic acid on leishmania (leishmania) amazonensis is related to programed cell death and presents therapeutic potential in experimental cutaneous leishmaniasis. PLOS ONE 10:e0144946. doi: 10.1371/journal.pone.0144946

Yamamoto, E. S., Campos, B. L., Laurenti, M. D., Lago, J. H., Grecco Sdos, S., Corbett, C. E., et al. (2014). Treatment with triterpenic fraction purified from Baccharis uncinella leaves inhibits Leishmania (Leishmania) amazonensis spreading and improves Th1 immune response in infected mice. Parasitol. Res. 113, 333-339. doi: 10.1007/s00436-013-3659-x

Conflict of Interest Statement: The authors declare that the research was conducted in the absence of any commercial or financial relationships that could be construed as a potential conflict of interest.

Copyright (C) 2019 Moraes Neto, Setúbal, Higino, Brelaz-de-Castro, da Silva and Aliança. This is an open-access article distributed under the terms of the Creative Commons Attribution License (CC BY). The use, distribution or reproduction in other forums is permitted, provided the original author(s) and the copyright owner(s) are credited and that the original publication in this journal is cited, in accordance with accepted academic practice. No use, distribution or reproduction is permitted which does not comply with these terms. 